\title{
Isparta Seferağa Camii ve Haziresi
}

\section{Emine GÜZEL"(i)}

\begin{abstract}
Öz: Anadolu'da hâkimiyet sürmüş ve hâkim olduğu bölgelerde başta cami olmak üzere çok sayıda eser bırakmış olan Selçuku, Beylikler ve Osmanlıların önemli eserlerinin yer aldığı yerlerden biri de Isparta ve çevresidir. Bu yörelerde yer alan camiler başta Osmanlı dönemi olmak üzere Selçuklu ve Hamitoğulları Beyliği'ne aittir. Özellikle Osmanlılar döneminde inşa edilen hemen her caminin bahçesinde ya da civarında bir de hazireye yer verilmiştir. Bu cami ve hazirelerden biri de Isparta iline bağlı Sütçüler ilçesinde bulunan Seferağa Camii'dir. Sonraki dönemlerde çok sayıda onarımlardan geçen ve böylelikle pek çok değişime uğrayan cami halen genel hatlarıyla erken dönem Osmanlı cami mimari üslubunu yansıtmaktadır. Bu çalışmamızda Seferağa Camii ile güneyindeki haziresi ele alınmıştır. Söz konusu eser tarihçe, mimari, plan, malzeme ve tektik ile süsleme özellikleri gibi yönleriyle incelenmiştir. Hazirede yer alan az sayıdaki mezar taşı ise tipoloji, yazı çeşidi ve tezyinat yönüyle incelenmiştir.
\end{abstract}

Anahtar Kelimeler: Isparta, Sütçüler, Seferağa Camii, Hazire, Mezar taşın.

\section{Isparta Seferaga Mosque and Cemetery}

Abstract: Isparta and its surroundings are one of the places where important Works of the Selçuks, Principalities and Ottomans who ruled in Anatolia and left many Works, especially mosques, in the regions the dominated. The mosques in these regions belong to the Selçuks and Hamitoğulları Principality, especially during the ottoman period. Especially there is a graveyard in the garden or in the vicinity of almost every mosque built during the Ottoman period. One of these mosques and graves is Seferağa Mosque located in Sütçüler district of Isparta province. The mosque which underwent many repairs and thus many changes in the following periods, still reflect the early Ottoman mosque architectural style in general. In this study Seferağa Mosque and its graveyard in the south were examined. The mosque has been studied in terms of its history, architecture, plan, materials, technical and ornamental features. The few gravestones in the gravyard site were analyzed in terms of typology, writing type and decoration.

Keywords: Isparta, Sütçüler, Seferağa Mosque, Gravyard, Tombstone. 


\section{Giriş}

Çalışma konumuzu "Isparta Seferağa Camii ve Haziresi" oluşturmaktadır. Seferağa Camii erken Osmanlı cami mimari üslubunda tek kubbeli, kare planlı bir camidir. Farklı yıllarda birçok kez yapım ve tamir gören camide bu gün için orijinalliğini koruyan asıl bölüm minaresidir. Son depremlerle caminin çeşitli bölümlerinde meydana gelen belirgin çatlaklar yakın bir gelecekte ceminin yeniden bir onarımdan geçmesini mümkün kılmaktadır.

İnsanoğlu tarih buyunca her daim yaşadığı ortamı, mekânları ve inancıyla ilgili kutsal gördüğü eşyaları güzelleştirme ve onlara estetik bir görünüm kazandırma çabasına girmiştir. Bu doğrultuda Müslümanlar için kutsal mekânlardan biri olan camiler de mümkün olduğunca figürden uzak bitkisel ve geometrik motiflerle dekore edilmiştir. Seferağa Camii'nde kubbe, kubbe kasnağı ve pencere kenar bordürleri yoğun kalem işi süslemelerle ve klasik Osmanlı süsleme motifleriyle tezyin edilmiştir. Caminin güney cephesinde yer alan hazire ise küçük olmakla beraber kitabelerindeki yazı karakteri ve süslemeleriyle dikkat çeker.

Çeşitli nedenlerle tahrip olan ya da kasıtlı olarak tahrip edilen tarihi camilerimiz ve hemen yanı başındaki hazirelerle geçmişimizin tapu senetleri konumundaki mezar taşları her geçen gün yok olmakla karşı karşıya kalmaktadır. Dolayısıyla kadim bir tarihe dayanan Seferağa Camii ve haziredeki mezar taşlarının incelenip kayıt altına alınmasının bu önemli mirasın gelecek kuşaklara aktarılması adına önemli olduğu kanısındayız.

\section{Isparta}

Isparta, Akdeniz Bölgesi'nin kuzeyinde Göller Bölgesinde yer alır. Kuzey ve kuzey batıdan Afyon, batıdan ve güneybatıdan Burdur, güneyden Antalya, doğu ve güneydoğudan ise Konya illeri ile çevrilidir. Yörede Lidyalılar, Frigler, Persler, Helenler, Romalılar, Bizanslılar, Selçuklular, Hamitoğulları Beyliği ve nihayet Osmanlılar hüküm sürmüşlerdir. 1204 yılında 3. Kılıç Arslan döneminde Türklerin eline geçen bölge, 1923 yılında bağımsız bir il hüviyetini kazanmış, 1926 yılında da Isparta adını almıştır. ${ }^{1}$

II. Kılıç Arslan zamanında (1156-1192) yoğunlaşan Bizans-Selçuklu savaşlarının en önemlisi olan Miryokefalon Savaşı 1176 yılında Isparta yöresinde vuku bul- 


\section{Emine GÜZEL \\ Isparta Seferağa Camii ve Haziresi}

muştur. Isparta ve çevresi tam olarak 1204 yılında Anadolu Selçuklu hükümdarı III. Kılıç Arslan döneminde ele geçirilmiştir. Anadolu Selçuklu Devleti'nden sonra önce Hamitoğulları Beyliği'ne geçen bölge (1301) son olarak 1390 yılında Osmanlı hâkimiyetine geçmiştir. ${ }^{2}$

Isparta tarih boyunca Orta Anadolu ile Ege ve Akdeniz bölgeleri arasında önemli bir kavşak noktası olmuş ve bunun bir sonucu olarak da pek çok kültürün kaynaştığı bir yer olmuştur.

\section{Sütçüler}

Isparta ilinin güneyinde bulunan ve il merkezine $101 \mathrm{~km}$ uzaklıkta olan ilçenin doğusunda Konya iline bağlı Beyşehir, Derebucak ve kuzey batısında Eğirdir, Güneyinde Antalya iline bağlı Serik ve Manavgat ilçeleri yer almaktadır. Güney batısında Burdur Bucak'la komşu olan Sütçüler ilçesi, kuzeydoğusunda ise Isparta ilinin Aksu ilçesiyle komşudur.

Günümüzde Isparta iline bağlı küçük bir ilçe konumunda olan Sütçüler (Resim 1) MÖ 130'da Romalılar tarafından ele geçirilerek MÖ 102-149 yılları arasında Kilikia eyaleti içine alınmıştır. Daha sonra Asia eyaletine bağlanan bölge Roma Imparatorluğu’nun MS 395 yılında parçalanmasının ardından Doğu Roma İmparatorluğu (Bizans) sınırları içinde kalmıştır. 1204'te Sütçüler ve çevresi civardaki şehirlerle birlikte Anadolu Selçuklu Devleti'nin hâkimiyetine geçmiştir. Anadolu Selçuklu Devleti'nden sonra önce Hamitoğulları Beyliği'ne geçen bölge, son olarak 1390 yılında Osmanlı hâkimiyetine geçmiştir. ${ }^{3}$

1888 yılında tespit edilen antik kentin kuruluşun tarihi tam olarak bilinmiyor olsa da şehrin adı ilk kez MÖ II. Yüzyılda Termassos'la yapılan bir anlaşmada "Adada" şeklinde yer almıştır. Adada olarak bilinen bölge Roma İmparatorluğu döneminde özellikle İmparator Traianus, Hadrianus ve Antoninus Pius dönemlerinde en parlak devrini yaşamıştır. ${ }^{4}$

Anadolu'da günümüze kadar gelebilmiş en sağlam yerleşimlerden biri olan Sütçüler İlçesinin kuruluşunun MÖ 200 yıllarına kadar dayandığı bilinmektedir. vd., Isparta Eko Turizm Parkurları Rehberi/Aksu, Eğirdir, Sürçüler Yenişarbademli (Isparta: Isparta Valiliği İ Kültür ve Turizm Müdürlüğü, 2014), 19.

3 Isparta/Sütçüler (Isparta:T.C. Isparta Valiliği III Kültür ve Turizm Müdürlüğü, 2012$), 2$.

4 Isparta/Sütçüler, 2. 
Ada'da olarak isimlendirilen bu antik kent Pisidya bölgesinde, Piyisdya Pamphiline bölgeleri arasında bulunmaktadır. Arkeoloji Literatüründe Adada olarak geçen kentin bir adının da Pavlu olduğu belirtilmiştir. Zira Pavlu ismi, buranın Türklerin eline geçmesinden sonra bile uzun süre kullanılmıştır. Bunun yanı sıra Pavlika olarak da anılan yöre, 1071 Malazgirt Zaferinden sonraki yıllarda Türklerin eline geçmiş olsa da, Türklerin hâkimiyetine kesin olarak girmesi 1224 Alaeddin Keykubat dönemine rastlar. Bu dönemde başta Atabey olmak üzere Isparta ve Eğirdir de Selçukluların hâkimiyetindedir. Hamitoğulları Beyliği'nin 1300 yıllarında Eğirdir'de varlık göstermesine kadar Sütçüler Selçukluların hâkimiyetinde kalmıştır. Seksen yıl kadar süren Selçuklu hâkimiyetinden günümüze bir Selçuklu eseri olarak Seferağa Camii kalmıştır. Daha sonra Hamitoğlu Beyliğine geçen bölge, beyliğin Osmanlı egemenliğine girmesinden sonra da bir süre Kara Bavlu olarak anılmıştır. ${ }^{5}$

Yıva (Pavlu) 1478-1501 tahrir kayıtlarında nahiye (zeamet), 1522 ve 1568 tahrir kayıtlarında kaza, Kâtip Çelebi'nin Cihannümasında ise kaza olarak görülmektedir. Sonrasında Bavullu şekline dönüşen isim, Cumhuriyet döneminde 1926 yılına kadar sürmüş bu tarihte ise dağlık anlamına gelen cebel ismini almıştır. Daha sonra Cebel Bucağı́nın teklifi ve il daimi encümen kararı ile yöre halkının İstanbul ve Ankara gibi büyük şehirlere süt ve süt ürünleri pazarlamacılığı yapması sebebiyle yörenin adı Sütçüler olarak değiştirilmiştir. Daha önce Eğirdir ilçesine bağlı iken, bucak merkezinin teklifi ile 28.05.1938 tarih ve 3919 sayılı resmi gazete yayımlanan 3393 sayılı kanunla Eğirdir İlçesinden ayrılarak Isparta'ya bağlı müstakil bir ilçe olmuştur. ${ }^{6}$

\section{Seferağa Camii ve Haziresi}

Isparta Seferağa Camii Isparta ili, Sütçüler ilçe merkezinde, eğimli bir arazi üzerinde ve ilçeye hâkim bir konumda inşa edilmiştir. Sütçüler merkezindeki tarihi öneme sahip ve klasik Osmanlı cami mimarisi üslubunu taşıyan en eski cami olarak bilinir.7 Bunu hem kitabesinde belirtilen tarihten hem de merkezî kubbesi ve kubbeye geçişte kullanılan pandantifler ile mukarnas bezemeli şerefesinde ve 


\section{Emine GÜZEL \\ Isparta Seferağa Camii ve Haziresi}

özellikle kubbe içinde kullanılan kalem işi bezeme motiflerinde görmek mümkündür. Zira klasik dönem mimarîsinde mukarnas kavsaralı mihrap nişleri, sivri kemerler, mandantifli kubbe geçişleri, minarelerde sivri külahın ve mukarnaslı şerefelerin tercihi gibi özellikler dikkat çeker. ${ }^{8}$ Caminin etrafında evvelce oldukça büyük bir alanı kaplayan ilçe mezarlığı bulunmaktayken 1940`lı yıllarda caminin onarım ve genişletme çalışmaları sırasında mezarlık kaldırılarak bugünkü ilçe girişi yakınlarına taşınmıştır. Caminin güneybatısında bulunan küçük bir hazire konumundaki alanda bulunan mezar taşları ise taşınan mezarlıktan geriye kalan mezar taşları olup buraya sembolik olarak bırakılmışlardır.

\section{Caminin Tarihi ve Bugünkü Durumu}

Pek çok kez tamir gören Seferağa Camii 1745 yılında Ömer Ağa oğlu Hasan Paşa tarafından, Çandır civarındaki Fieyhler (Tekke) köyünde defnedilmiş olan Şeyh Muhammed Efendi’nin isteğiyle tekrar esaslı bir tamir görmüştür. Caminin biri harime giriş kapısı üzerinde mermer, diğeri de minarenin etrafı sonradan demir parmaklıklı camekân ile kapatılmış son cemaat yerinde kalan kaidesinde taş olmak üzere iki adet kitabesi mevcuttur (Resim 2, 3). Minarenin son cemaat bağlantı yerindeki H.1158/M.1745 tarihli kitabede, "Sâhibü'l-hayrat Hasan Mısrî Paşa/ Bâşa İbn-i Ömer Ağa" yazılıdır (Resim 4, 5). Kapı üzerindeki kitabenin 20. ve 21. beyitlerinde ise kitabeyi yazanın isminin hattat Halil Efendi olduğu ve "Hafız" kelimesinde de tarihi düşülerek, ebced hesabıyla, H.998/M.1590 yılında tamamlandığı belirtilmektedir (Resim 6). ${ }^{9}$

Toplam 21 beyitten oluşan kapı üzerindeki bu kitabeye göre caminin yapımının kitabenin birinci beytinde ifade edildiği üzere Sefer Ağa'nın vasiyeti ile ve özellikle de Şeyh Mehmet Efendi'nin vesilesiyle olduğu, Hasan Paşa tarafından da tamamladığı anlaşılmaktadır. Harime giriş kapısı üzerinde bulunan mermer kitabede ise H.1184/M.1771 tarihi ile caminin, H.998/M.1590 tarihi ile de minarenin yapım tarihi belirtilmiştir. Ana kapının üst kısmında yer alan 21 beyitlik kitabede tarih düşülerek verilen H.998/M.1590 tarihi göz önünde bulundurulduğunda mermer kitabedeki tarihin caminin onarım kitabesi olduğunu söylemek mümkündür. Zira farklı kaynaklarda caminin inşa tarihi H.696/M.1296 yılında Selçuklu Devleti'nin (1076-1308) son zamanlarına tarihlendirilmekte, H.998/M.1590 'yılın- 
da (III. Murat devri) da tamir edildiği ifade edilmektedir. Yine eserin zamanla yıpranınca Muhiddin b. Şeyh Muhammed tarafından yıktırılarak yeniden yaptırıldığı ve son olarak 1955-1959 ile 1977 yıllarında tekrar restore edildiği de kaynaklarda geçen bilgiler arasındadır. ${ }^{10}$ Yapılan bu son restorasyon çalışmalarında Vakıflar Genel Müdürlüğü tarafından esaslı bir onarıma tabi tutulan ve içi hüsn-i hat ve kalem işleriyle tezyin edilen yapı halen ibadete açıktır (Resim 7).

\section{Plân}

Tek kubbeli klasik Osmanlı cami mimarisi üslubunu taşıyan eserde ${ }^{11}$ kare plânIı ana mekânı örten kubbeye geçiş, köşelerde yer alan tromplarla sağlanmakta olup kubbe dıştan kurşunla kaplanmıştır (Resim 8, 9). Caminin kuzeyinde ise 4 mermer sütuna oturtulmuş sivri kemerlerden oluşan ve günümüzde camekânla kapatılmış olan 3 gözlü son cemaat yeri bulunmaktadır. Kesme taş malzemeden yapılmış orijinal minaresi ise yapının kuzeybatı köşesine bitişik bir konumdadır (Resim 7,10).

\section{Dış Mekân}

Tek kubbeli ve kare plânlı bir yapıda olan cami, kesme ve moloz taş kullanılarak yapılmış olup üzeri kurşun kaplı kubbe ile örtülmüştür. Kuzey cephesinde dört sütuna oturtulmuş sivri kemerlerin oluşturduğu üç gözlü son cemaat yeri bulunan caminin asıl ibadet mahalli sekizgen ve yüksek bir kasnağa oturtulan büyük bir kubbeyle örtülü iken ortada giriş kapısıyla son cemaat mahalli ise üç küçük kubbe ile örtülmüştür (Resim 7, 10). Sade başlıklı dört adet sütun üzerine oturtulmuş sivri kemerlerin oluşturduğu son cemaat yerinde yanlarda iki küçük mihrabiye yer almaktadır. Miharabiye kavsaraları taşların kademeli olarak yükseltilmesiyle hareketlendirilerek mukarnas görünümü kazandırılmıştır. (Resim 11, 12). Kare plânlı Caminin minaresi kuzeybatı köşesinde yer alan minaresi kesme taştan yapılmış olup silindir formlu bir gövdeye sahiptir (Resim 13, 14). minare, tek şerefeli olup şerefe altlığı sıralı üçgen prizmalarla hareketlendirilerek mukarnas

10 (https://gag.wikipedia.org/wiki/Dosye:Sefera\%C4\%9Fa_Cami_YT_1184.jpg /; (https://isparta. ktb.gov.tr/TR-70964/camiler.html

11 Tek kubbeli cami mimarisi için bkz. Metin Sözen, Türk Mimarisinin Gelişimi ve Mimar Sinan (İstanbul: Türkiye İş Bankası Kültür Yayınları, 1975); Oktay Aslanapa, Osmanlı Mimarisi (İstanbul: Türkiye İş Bankası Kültür Yayınları, 1996) 


\section{Emine GÜZEL \\ Isparta Seferağa Camii ve Haziresi}

görünümü kazandırılmıştır (Resim 15). Silindir formlu gövde, üçgenlerle oluşturulan pabuçluğuyla sekizgen formlu yüksek bir kaide üzerinde yükselir. Orijinal halini koruyan tek şerefeli minarenin külahı kurşunla kaplıdır (Resim 16).

Batı cephesinde aşağıdan yukarıya simetrik olarak sıralanmış altı adet pencere açıklığı bulunmaktadır. Yukarıda kalan dört açıklık mazgal pencere formunda olup yuvarlak kemerli iken alt sıradaki iki açıklık ise nispeten daha büyük olup sivri kemerli ve demir parmaklıklarla kapatılmıştır (Resim 17, 18). Doğu ve güney cephede ise aynı formda ve aynı istifle sıralanmış beş adet pencere açıklığı bulunmaktadır. Üst kısımları yuvarlak kemer şeklinde düzenlenmiş olan dikdörtgen formlu açıklıklardan yukarıda kalanlar mazgal pencere formatında iken alt sıradaki iki açıklık ise daha büyük olup demir parmaklıklarla kapatılmıştır (Resim 19, 20). Güney duvarında yer alan pencerelerden birinin (sağ alt pencere) hemen yanında sonraki yıllarda onarımlar sırasında konulduğunu düşündüğümüz beyaz bir taş üzerine özentisiz bir şekilde tek minaresiyle caminin resmi kazınmıştır (Resim 21).

Caminin iki girişi bulunmaktadır. Bunlardan ilki etrafı sonradan camekânlarla kapatılmış olan son cemaat yerine açılırken diğeri asıl ibadet mekânına açılmaktadır. Caminin hârim bölümüne girişi sağlayan mavi renkli ahşap kapı, sade bir yapıda olup basık kemerli bir formdadır. Kapının sol tarafında üzerinde cami ve minarenin yapıp tarihlerinin yazılı olduğu mermer bir kitabe bulunmaktadır. Üst bölümünde ise kaş kemerle sınırlandırılmış bir alınlık ile bu alınlık içerisinde yer alan ikinci bir kitabe bulunmaktadır. Kitabenin hemen üzerindeki bölümde ise dikdörtgen formlu bir mazgal pencere yer almaktadır. (Resim 22, 23). Üç küçük kubbeyle örtülü olan son cemaat yerinde kubbe merkezi ile kubbeye geçişi sağlayan üçgen pandantif yüzeyleri palmet ve rumilerin oluşturduğu kalem işi bitkisel motiflerle süslenmiştir. Kubbe göbeğindeki tezyinat, merkezinde sekiz köşeli bir yıldız ve çevresinde haçvari bir motif ile palmet ve rumilerden oluşan, en dışta her biri bir palmet ile sonlanan sekizgen şemse formunda bir düzenleme şeklinde olup, kubbe geçişlerindekiler ise içerisinde yine palmet ve rumilerin yer aldığı ve etrafında üç dilimli yaprak şeklindeki üçgenlerin sıralandığı dairesel bir düzenleme şeklindedir (Resim 24, 25).

Caminin kuzey batı köşesinde ise etrafı kapatılmış ve üzeri kubbeyle örtülü sekizgen formlu bir şadırvan bulunmaktadır (Resim 26, 27). 


\section{İç Mekân}

Kare planlı camide kubbeye geçiş tromp ve kubbe eteği boyunca sıralanan sağır kemer şeklinde düzenlenmiş yuvarlak kemerler ile bu kemerlerin meydana getirdiği pandantiflerle sağlanmıştır. (Resim 8, 9). İç mekânda ayrıca her cephede duvar yüksekliğinde dekoratif amaçlı düzenlenmiş yuvarlak kemer yüzeyleri renkli kalemişi ile tezyin edilmiştir (Resim 28, 29). Mihrap duvarında ve mihrabın hemen üzerinde biri altta ikisi ise üste simetrik olarak yerleştirilmiş vitray tarzında düzenlenmiş sivri kemerli üç adet pencere ile en altta biri mihrabın sağında diğeri solunda olmak üzere dikdörtgen formlu iki adet ahşap pencere yer almaktadır (Resim 30).

Mihrap duvarındaki pencere sayı ve sistemi doğu duvarında tekrar edilmiştir (Resim 31). Batı duvarında ise ikisi altta ikisi üstte olmak üzere simetrik olarak yerleştirilmiş vitray tarzında düzenlenmiş dört adet pencere ile en altta simetrik olarak yerleştirilmiş dikdörtgen formlu iki adet ahşap pencere yer almaktadır ( Resim 32). Harim kısmının kuzey duvarında üstte kadınlar mahfili yer almaktadır. Kadınlar mahfilinin alt bölümü imam odası ile yerden yüksekçe yapılmış sağlı sollu iki ayrı namaz bölümü şeklinde düzenlenmiştir (Resim 33 )

Kıble duvarında yer alan mihrap oldukça sade bir yapıda olup yağlı boya ile yapılmış perde motifiyle süslenmiştir (Resim 34). Hemen sağındaki ahşap minber ise son dönem yapımı olup günümüz ahşap tekniği uygulanmıştır (Resim 35, 36).

\section{Malzeme ve Teknik}

Cami yapımında malzeme olarak moloz ve kesme taş ile ahşap, harç ve tuğla kullanılmıştır. Kadınlar mahfili, minber ve vaaz kürsü ile imam odası gibi bölümlerde ise günümüz ahşap malzeme özelliği ve tekniği uygulanmıştır.

\section{Süsleme}

Seferağa Camii genel olarak sade bir yapıya sahiptir. Bununla birlikte yapının bazı bölümlerinde klasik Osmanlı üslubu tezyinat görülür. Tezyinat daha çok kubbe, kubbe eteği, kubbeye geçiş unsurları, duvar yüzeylerindeki kemer kuşakları ve pencere çerçevelerinde yoğunlaşmıştır.

Anadolu Türk Sanatı geleneğinin bir devamı olarak en erken kalemişi örnekleri geometrik desenler, rozetler, rumî ve palmetlerin yer aldığı bir kompozisyon 
şeklinde çoğunlukla mimarî yapıların kubbe, tonoz ve kubbeye geçiş unsurları üzerinde uygulanmıştır. Bununla birlikte Osmanlı mimarisinde klasik dönemin sonunda kadar kalemişi süslemelerinde genellikle rumi, palmet ve Orta Asya'dan İran vasıtasıyla Anadoluy'a gelerek en yaygın kullanım alanına Osmanlılar devrinde ulaşan hatâyînin ${ }^{12}$ yanı sıra kıvrık dal ve yapraklarla yıldız ve madalyon motifleri de söz konusu eserde görülen süsleme motifleri olarak karşımıza çıkmaktadır.

\section{Dış Mekân}

Seferağa Camii, eğimli bir arazi üzerine inşa edilmiştir. Eser, merkezî plânlı tek kubbesi, her biri kubbeyle örtülü üç gözlü son cemaat yeri ve tek şerefeli taş minaresi ile küçük bir Osmanlı camisi formundadır (Resim 7, 10, 13). Plân ve malzeme özellikleri yönüyle eser, Isparta il merkezindeki Mimar Sinan ve Atabey'deki Burhaneddin Paşa Camileri ile benzer özellik taşır.

Sivri kemerle dışa açılan son cemaat yeri, üç adet sivri kemer ile başlık ve gövde kısımları oldukça sadece üç sütun üzerine oturur (Resim 10, 13).

Caminin kuzeybatı köşesinde yer alan tek şerefeli minaresi kesme taştan yapılmış silindir formlu gövdeye sahiptir. Silindir formlu gövde, üçgenlerle oluşturulan pabuçluğuyla altıgen formlu yüksek bir kaide üzerinde yükselir. Orijinal halini koruyan tek şerefeli minarenin külahı, kurşunla kaplıdır. Minare, sekizgen prizma formlu bir kaideye sahiptir. Kaideden yüzeyleri tersli düzlü üçgenlerle pahlı pabuç kısmına geçilmektedir. Caminin, çatı hizasına kadar gittikçe daralarak yükselen bu bölümden sonra, dairesel formlu, hafif dışa taşkın bir forma sahip bilezikle gövde yükselir. Oldukça kısa olan gövde, son derece sade olup yüzeyinde herhangi bir tezyinata yer verilmemiştir. Gövde üst kısmında yer alan ikinci bir bilezikten sonra şerefeye geçilir. Şerefe altlığı sıralı üçgen prizmalarla hareketlendirilerek mukarnas görünümü kazandırılmıştır. Minarenin petek kısmı da bütünlükle uyumlu olarak sade bir yapıda olup zaman içerisinde onarımlardan geçmiştir. Külah kısmı ise kurşunla kaplıdır. (Resim 13, 14, 15, 16).

Doğu ve batı duvarları tamirat görmüş olan caminin bu bölümlerindeki pencere kemerleri ve alınlıkları orijinaldir (Resim 18, 19). 
Kuzey cephede bulunan üç gözlü son cemaat yerinde girişi sağlayan kapıdan başka bir de asıl ibadet mekânı olan harime girişi sağlayan ikinci bir kapı yer alır. Son dönem yapımı olan mavi renkli ahşap kapı basık kemerlidir. Kapı kemerinin üstünde yer alan kaş kemerli alınlığa sahip bölümde sonraki bölümde detaylandıracağımız yeşil ve sarı renkle boyalı 21 beyitten oluşan bir kitabe yer alır. Yatay yönde gelişen satırlar halinde ve sülüs hatla yazıımış olan kitabede her bir satır, üçerli gruplandırılarak yine yatay yönde gelişen oval kartuşlar içine alınmıştır. Kartuş aralarında meydana gelen yıldız formlu boşluklara daire, kanar boşluklarında ise yarım daire formlu geometrik motifler yerleştirilmiştir. Kitabe çerçevesi ile daireler yeşil renle boyanmışken, kartuş çerçeveleri ile kenar boşluklarından yer alan yarım daireler sarı renge boyanmıştır. Kitabe, her bir kartuşta iki satır olarak toplam 42 satırdan oluşmaktadır (Resim 6).

Kuzeyde cephedeki üç gözlü son cemaat yerini örten kubbelerin iç yüzeyleri beyaz badanalı olup, kubbe göbeği ile pandantiflerde mavi ve kırmızı yoğunluklu geleneksel Türk renklerinin kullanıldığı kalem işi bezemeler yer almaktadır. Harimde kubbe içi, pencere kenarları ve pandantiflerde de görülen aynı tarz bezemelerin bir kısmı orijinal olmakla beraber büyük bir kısmı aynı desenler üzerinden gidilmek suretiyle tamir edilmiştir. Kubbe göbeğindeki tezyinat, merkezinde sekiz köşeli bir yıldız ve çevresinde haçvari bir motif ile palmet ve rumilerden oluşan, en dışta her biri bir palmet ile sonlanan sekizgen şemse formunda bir düzenleme şeklinde olup, kubbeye geçişi sağlayan pandantiflerde ise ortada iri bir yaprak ile palmet ve rumilerin yer aldığı, etrafında üç dilimli yaprak şeklindeki üçgenlerin sıralandığı dairesel bir düzenleme şeklindedir (Re$\operatorname{sim} 8,9)$.

Kuzey duvarının doğu ve batı bölümlerinde simetrik olarak yerleştirilmiş iki adet mihrabiye bulunmaktadır. Yüzeyleri sade ve bezemesiz olan mihrabiye kavsaraları taşların kademeli olarak yükseltilmesiyle hareketlendirilerek mukarnas görünümü kazandırılmıştır (Resim 11, 12).

\section{İç Mekân:}

Tek kubbeli plân tipine sahip olan yapıda iç mekânda kubbeyi taşıyan duvar içindeki kemerler dekoratif amaçlı düzenlenmiş friz kuşakları ile belirginleştirilmiştir. Güney duvarında bulunan taş mihrap oldukça sade bir yapıdadır. Mihrapta dikkati çeken tek özellik yeşil, kırmızı ve mavi renklerin kullanıldığı yağlı boya 
ile yapılmış bir perde motifiyle bezenmiş olmasıdır. Miharabı üç yönden kuşatmış olan silmeler ise kahverengiyle boyalıdır. Mihrap kavsarası taşların kademeli olarak yükseltilmesiyle hareketlendirilerek mukarnas görünümü kazandırılmış, kavsaranın tepe kısmı ise istiridye kabuğu şeklinde düzenlenmiştir. (Resim 34).

Cami iç mekânında dikkat çeken en belirgin bezeme unsurları kubbe içi, pandantifler, kubbeyi taşıyan kemer yüzeylerini dolaşan friz kuşakları ve pencere kenar sövelerinde görülen kalem işi bezemelerdir. Farklı renk ve tonların kullanıldığı klasik Osmanlı tarzındaki bu bezemelerin bir kısmı orijinalliğini korumuş olmakla beraber çoğu sonraki süreçlerde gerçekleştirilen onarımlarla yeniden şekillendirilmiştir.

Kubbe tavan göbeğinde görülen motifler merkezden kubbe yüzeyine paralel bir şekilde açılan dairesel bir madalyondan yıldız şeklinde etrafa saçılan motifler ve irili ufaklı madalyonlar, yıldızlar, şemseler şeklindedir. Pandantif yüzeylerinde de görülen benzer yoğun süsleme, kubbe eteğinde saçak bezemesi şeklinde düzenlenmiştir. (Resim 8, 9). Bu özellikleriyle de klasik Osmanlı dönemine tarihlenen yapı, dönemin en önemli eserlerinden biri olmuştur.

Minber ve vaaz kürsüsü tamamen günümüz malzemesi (çam) ve günümüz oyma tekniğinin kullanıldığı ahşap işçiliklidir. Minberin külah, tepelik, aynalık ve merdiven korkulukları bölümlerinde kafes oyma tekniği uygulanmıştır. Merdiven korkulukları S ve $C$ kıvrımları şeklinde düzenlenmiş akantus yapraklarılyla tezyin edilmiştir Yan aynalıklarda ortada güneş kursu ve etrafında yine $S$ ve $C$ kıvrımlı akantus yaprağı motifleri ile kenar bordürlerinde kıvrık dal ve yapraklarıyla beş yapraklı çiçek motiflerine yer verilmiştir. Üç dilimli kemer şeklinde düzenlenmiş süpürgelikler de aynı formdaki $S$ ve $C$ kıvrımlı akantus yapraklarıyla tezyin edilmiştir (Resim 35, 36, 37, 38, 39). Kafes oyma tekniğinin uygulandığı minber tepeliğinde de yine $\mathrm{S}$ ve $\mathrm{C}$ kıvrımları şeklinde hareketlendirilmiş akantus yapraklarıyla ortasında Lafzatullah'a (الله) yer verilmiştir. Minber aynalığında ise yine kafes oyma tekniğiyle Kelime-i Şehadet " لإ إله إلا الله محمد رسول الله iberesiyle sağ ve solunda الله varimleri ile 1991 ve 1992 tarihlerine yer verilmiştir. Üç dilimli bir forma sahip olan minber kapı kemeri yüzeyi de benzer formadaki $S$ ve $C$ kıvrımlı akantus yapraklarıyla tezyin edilmiştir. Yüzeyi yaprak ve beş dilimli çiçek motifleriyle bezenmiş sütuncelerin başlıklarında da yine kafes oyma tekniğiyle yazılmış" اللهمد ve isimlerine yer verilmiştir (Resim 39) 


\section{Camide Yer Alan Kitabeler}

Cami dış mekânında toplam üç adet kitabe bulunmaktadır Bunlardan biri harim giriş kapısının solunda, diğeri üst kısmında bir diğeri ise minarenin son cemaat bölümünde kalan kaidesi üzerinde yer almaktadır (Resim 2, 3, 4, 5, 6).

Ana giriş kapısının sol tarafında yer alan mermer kitabede (Resim 3) Latin harfleriyle şu ifade yazılıdır:

\section{Seferağa Camii Y. T.1184}

Minare kaidesinde bulunan kitabede ise Arapça olarak şu ifade yazılıdır:

\section{"Sahibü'l-hayrât Hasan Mısrî Paşa/Bâşa ibn-i Ömer Ağa"}

Ana giriş kapısının üst kısmında bulunan 21 beyitlik kitabe kitabenin (Resim6) yöre sakinlerinden biri tarafından yazılmış el yazması bir nüshası caminin harim batı duvarına bırakılmıştır. Kitabenin son satırına ayrıc حفيظ kelimesine düşülen q9^ " şeklindeki tarih ibaresiyle muhtemelen kitabeyi yazıya aktaran kişinin isminin belirtildiği ve bunu yazıya aktardığı tarihin yer aldığı

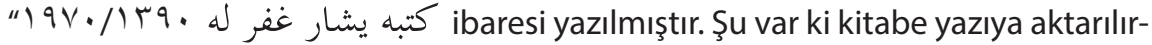
ken bazı kelimeler hatalı olarak yazılmıştır. Yeniden ele aldığımız kitabenin metni şu şekildedir:

\begin{tabular}{|c|c|c|}
\hline 3 & 2 & 1 \\
\hline ياييلوب قالدى جون اوملا دى زائر & و يا ييلسون لوا ايخينده اولسون آباد & سفر آغا وصيت ايتدي مرغوب \\
\hline نيجه ييللر معطل اولدى & بنى ايتسون كورنلر خيرله ياد & ديدي بر روحى ايجون بر جامع ايجون \\
\hline \multirow{3}{*}{$\begin{array}{l}\text { Yapılıp kaldı çün olmadı zâir } \\
\text { Nice yıllar muattal oldu }\end{array}$} & \multirow{3}{*}{$\begin{array}{l}\text { Ve yapılsın liva içinde } \\
\text { olsun âbâd } \\
\text { Beni etsin görenler hayırla } \\
\text { yâd }\end{array}$} & Sefer Ağa vasiyet etti mergûb \\
\hline & & Dedi bir ruhi içün bir cami' \\
\hline & & \\
\hline & 5 & 4 \\
\hline داخى آتاسى ابراهيمه يا رب & معين اولدى آكا قره ده نبى الياس & حسن ايتدى تمام بو سجده كاهى \\
\hline سن ايت رحت يدى جدى ايله & رفيقى اولسون آنك حضر الياس & قبول ايله سن آنى يا الهى \\
\hline \multirow[t]{2}{*}{$\begin{array}{l}\text { Dâhi atası İbrahime Yâ Râb } \\
\text { Sen et rahmet yedi ceddi ile }\end{array}$} & \multirow{2}{*}{$\begin{array}{l}\text { Muayyen oldu ona karada } \\
\text { nebi Illyas } \\
\text { Refiki olsun ânın Hızır İlyas }\end{array}$} & \multirow{2}{*}{$\begin{array}{l}\text { Hasen etti tamam bu secde- } \\
\text { gâhı } \\
\text { Kabul eyle sen ânı yâ ilâhi }\end{array}$} \\
\hline & & \\
\hline 9 & 8 & 7 \\
\hline فناده انجق الور بويله محفل & تمام اولدى ياييلدى بيت الله & كشت اولوب طوراغى هر برينك \\
\hline بقاده ويره الله يوجه منزيل & كرنلر هب ديديلر بارك الله & و آلالر ثيابى نيجه حورى عينك \\
\hline
\end{tabular}




\begin{tabular}{|c|c|c|}
\hline $\begin{array}{l}\text { Fenâda ancak olur böyle } \\
\text { mahfil } \\
\text { Bekâda vere Allah yüce } \\
\text { menzil }\end{array}$ & $\begin{array}{l}\text { Tamam oldu yapıldı Bey- } \\
\text { tu'l-lah } \\
\text { Görenler hep dediler } \\
\text { bârekallah }\end{array}$ & $\begin{array}{l}\text { Behişt(cennet) olup durağı } \\
\text { her birinin } \\
\text { Ve alalar siyabi nice huri aynin }\end{array}$ \\
\hline 12 & 11 & 10 \\
\hline مقاماتنى ايده عدن اعلى بودى تعلى & ملكلر حوريلر يولداشى اولسون ايجره اولسون & تربن كلشن طوراغه ده حق رحمت ايتسون \\
\hline $\begin{array}{l}\text { Niyazımız budur bâri Te'âlâ } \\
\text { Makâmâtını ede adn-ı a'lâ }\end{array}$ & $\begin{array}{l}\text { Yürüsün cennet içre olsun } \\
\text { Melekler huriler yoldaşı } \\
\text { olsun }\end{array}$ & $\begin{array}{l}\text { Safer Ağa'ya da hak rahmet } \\
\text { etsin } \\
\text { Türbeni gülşen durağın cen- } \\
\text { net etsin. }\end{array}$ \\
\hline وصيتدن آلوب جمله مالي & خصوصا شيخ محمد افندى اولدى سبب بالذات كندى 14 & سبب اولنلره سرمنيجون ربله عزت رحت \\
\hline $\begin{array}{l}\text { Vasiyetten alıp cümle mâlı } \\
\text { Eriştirdi kemâle bu mâlı }\end{array}$ & $\begin{array}{l}\text { Hususan Şeyh Muhammed } \\
\text { Efendi } \\
\text { Ona oldu sebep bizzat } \\
\text { kendi }\end{array}$ & $\begin{array}{l}\text { Resulün hürmeti için Rabbi } \\
\text { İzzet } \\
\text { Sebep olanlara sen eyle rah- } \\
\text { met }\end{array}$ \\
\hline شحيمك ايت آنلرى بونلره يا رين & 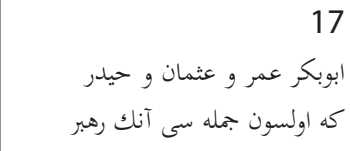 & 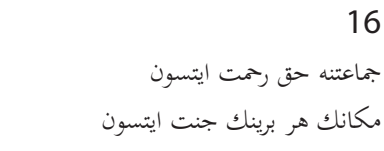 \\
\hline $\begin{array}{l}\text { Şefi 'et onları bunlara yarın } \\
\text { Cehimin görmesin hiçbiri } \\
\text { nârın }\end{array}$ & $\begin{array}{l}\text { Ebubekir Ömer ve Osman } \\
\text { ve Haydar } \\
\text { Ki olsun cümlesin anın } \\
\text { rehber }\end{array}$ & $\begin{array}{l}\text { Cemaatine hak rahmet etsin } \\
\text { Mekânın her birinin cennet } \\
\text { etsin }\end{array}$ \\
\hline بازانه خير دعا قيلمغ يادكار اولمغيجون & حتمنام الله خليل افندى 20 حفئده تاريخى بولدى & 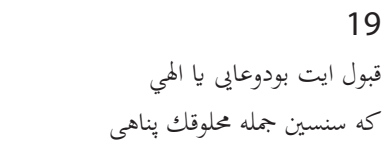 \\
\hline $\begin{array}{l}\text { Bunu yazdım yâdigar olmak } \\
\text { için } \\
\text { Yazana hayır dua kılmak içün }\end{array}$ & $\begin{array}{l}\text { Tamamının Allah Halil } \\
\text { Efendi } \\
\text { Hâfız isminde tarihi buldu. }\end{array}$ & $\begin{array}{l}\text { Kabul et bu duayı ya ilahi } \\
\text { Ki sensin cümle mahlûkun } \\
\text { penâhı (koruyucusu) }\end{array}$ \\
\hline
\end{tabular}

ابوبكر الله، محمد، عمر، Caminin harimi örten merkezi kubbe eteğinde sırasıyla ( Ebubekir, Hasan, Ali, Ömer, Muhammed, Allah, Osman, Hüseyin) isimleri yazılıdır (Resim 8, 9, 40). 


\section{Cami Haziresi}

Seferağa Camii haziresi, caminin güneybatı köşesinde bir grup ağaç arasında kalmış oldukça küçük bir hazire şeklindedir (Resim 41). Hazirede biri üst bölümden, diğeri alt bölümden kırık bir durumda olan toplam beş adet mezar taşı bulunmaktadır. Evvelce Caminin etrafında oldukça büyük bir alanı kaplayan ilçe mezarlığı bulunmaktayken 1940'lı yıllarda caminin onarım ve genişletme çalışmaları sırasında mezarlık kaldırılarak bugünkü ilçe girişi yakınlarına taşınmıştır. Mezarlıkta yer alan pek çok mezar taşı tahrip edilmiş, bir kısmı ise taşınan yeni mezarlık alanına gelişi güzel bırakılmıştır. Küçük bir hazire olarak düzenlenen bu bölümde yer alan mezar taşları da taşınan mezarlıktan geriye kalanlar olarak cami bahçesinde muhafaza edilmektedir.

Mezar taşı kitabelerinin hepsinde yazılar sülüs hatla ve kabartma tekniğinde yazılmıştır. Yazılarda dikkat çeken en önemli özellik ise harflerin kuyruk ya da çanak kısımlarının çiçek ve yaprak şeklindeki bitkisel motiflerle tezyin edilmiş olması, bazılarında ise aralardaki boşlukların stilize çiçek motifleriyle doldurulmuş olmasıdır. Mezar taşlarında pek az örneğine rastlanan benzer bir uygulama Malatya Sancaktar Mezarlığı'ndaki bir mezar taşı kitabesinde görülür. ${ }^{13}$

Mezar taşlarının ikisinde sarığın başlık üzerine yukarıdan aşağıya düşey olarak sarılmasıyla düşey dilimli başlık şeklinde adlandırılan ${ }^{14}$ ve sarıklık kumaşın kavuk, külah ya da fes gibi farklı şekillerde olabilen başlık üzerine bir halat gibi burulmasından dolayı burma sarık olarak da isimlendirilen ${ }^{15}$ başıิık türü kullanılmış$\operatorname{tir}(\operatorname{Resim~1a,~1b,~3a,~3b).~}$

Mezar taşı kitabelerinden edinilen bilgiler ışığında daha ziyade İstanbul, Bursa ve Edirne civarında rastlanan ve 16. yüzyıla tarihlenen bu tip başlıkları Eyüp Sultan'da Sokullu Mehmet Paşa türbesi civarındaki birçok mezar taşında görmek mümkündür. Bunlardan biri Kanuni Sultan Süeyman ve ve Sultan II. Selim dönemi vezirlerinden Lala Mustafa Paşa'ya aittir (M.1580) (Resim 42, 43). Benzer örnekler Malatya Sancaktar Mezarlığı'nda da görülmüştür (Resim 44, 45) ${ }^{16}$.

Emine Güzel, Malatya Sancaktar Mezarlığı́ndaki Osmanlı Dönemi Mezar Taşları (Konya: Çizgi Yayınevi, 2020), 443.

14 Halit Çal, "İstanbul Eyüp’teki Erkek Mezar Taşlarında Başlıklar”, Tarihi Kültürü ve Sanatıyla Eyüpsultan Sempozyumu III, Tebliğler, (28-30 Mayıs, 1999). (İstanbul: Eyüpsultan Belediyesi Yayınları, 2000), 208.

16 Güzel, Malatya Sancaktar Mezarlığı́ndaki Osmanlı Dönemi Mezar Taşları, 443. 
Heybetli görünümünden dolayı cengâverlik ve kabadayılık gibi vasıfların göstergesi olarak görülen, düz sarığa nazaran daha geç kirlenme ya da kirini kolayca belli etmeme gibi özelliklere de sahip olan bu bu tür başlıkların ${ }^{17}$ en eski örneği Eyüp'teki Karyağdı Sokak'ta bulunan, 2 Zilhicce 918'de (9.1.1513) ölen Derviş Mehmet b. Mesih'in mezar taşıdır. ${ }^{18}$

XVI. yüzyılın başlarından itibaren görülen ancak XVII. yüzyılın sonlarına doğru kullanımdan kalkan bu tip başlıklar, zenginliğin bir ifadesi olarak iri sorguç kabartmaları ile süslenmiştir. ${ }^{19}$ Bu tür başlıkları sultanlar, sadrazam, vezir ve paşa gibi üst düzey devlet görevlilerinin mezar taşlarında görmek mümkündür. hattin Dilidüzgün (İstanbul : Tarih Vakfı Yurt Yayınları, 1997),141

19 Süleyman Berk, Zeytin Burnu'nun Tarihi Mezar Taşları/Zamanı Aşan Taşlar (İstanbul: Zeytinburnu Belediyesi Kültür Yayınları, 2006), 30 


\section{MÎZÂNÜ'L-HAK}

ISLAMI ILIMLER DERGISI

\begin{tabular}{|c|c|}
\hline \multicolumn{2}{|c|}{ 1. Numaralı Mezar Taşı } \\
\hline $\begin{array}{c}\text { Fotoğraf 1a:1 numaralı mezar taşı ve ön } \\
\text { yüzeyindeki kitabe }\end{array}$ & $\begin{array}{l}\text { Fotoğraf } 1 \mathbf{b}: 1 \text { numaralı mezar taşı ile ön ve } \\
\text { yan yüzeylerindeki kitabeler }\end{array}$ \\
\hline 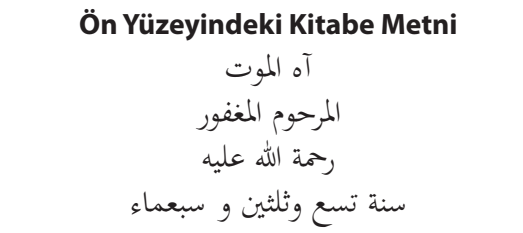 & $\begin{array}{c}\text { Okunuşu } \\
\text { Ah el-mevt } \\
\text { el-merhûm el-meğfûr } \\
\text { rahmeti'l-lahi aleyhi } \\
\text { Sene tis'a ve selâsîne ve seb'amie }\end{array}$ \\
\hline $\begin{array}{l}\text { Fotoğraf 1c: } 1 \text { numaralı mezar taşı ve yan } \\
\text { yüzeyindeki kitabe }\end{array}$ & $\begin{array}{l}\text { Fotoğraf 1d: } 1 \text { numaralı mezar taşı ve yan } \\
\text { yüzeyindeki kitabe }\end{array}$ \\
\hline $\begin{array}{c}\text { Yan Yüzeyindeki Kitabe Metni } \\
\text { الى دار السرور } \\
\text { Okunuşu } \\
\text { İlâ dâru'l-surûr }\end{array}$ & $\begin{array}{l}\text { Yan Yüzeyindeki Kitabe Metni } \\
\qquad \begin{array}{c}\text { الى دار الى } \\
\text { Okunuşu } \\
\text { İlâ dâru'l-bekâ }\end{array}\end{array}$ \\
\hline
\end{tabular}


Tanım: Bir baş şahidesi olan ve dikdörtgen prizma formundaki mezar taşında burma sarıkIı kavuk türünde bir başıık kullanılmıştır. Üzerindeki destarların çift kat olarak tasarlandığı başlıkta destarlar arsında iki adet gül motifi yerleştirilmiştir (Fotoğraf $1 a, b$ ). Yatay yönde gelişen satırlar halinde sülüs hatla ve kabartma tekniğiyle yazılmış olan ön yüzeyindeki kitabede serlevha ibaresi sivri kemer formundaki bir kartuş içine alınmışken diğer satırlar yatay yönde gelişen dikdörtgen formlu kartuşlar içine alınmıştır (Fotoğraf 1a). Şahidenin dikey yönde gelişen tek satır halinde sülüs hatla ve kabartma tekniğiyle yazıımış olan yan yüzeyindeki kitabe ise yine dikey yönde gelişen dikdörtgen formlu bir kartuş içine alınmıştır (Fotoğraf 1c). Kitabelerde dikkat çeken husus ön yüzeydeki kitabenin serlevha ibaresindeki vav " 9 " harfinin kuyruk kısmının, yan yüzeylerindeki kitabelerde ise dal "د" harfinin üst kısmının birinde stilize yaprak, diğerinde ise lale motifi şeklinde düzenlenmiş, kaf " harfi ile ye "ي" harfinin üst kısmında da stilize çiçek motiflerine yer verilmiştir (Fotoğraf 1a, c,d). 


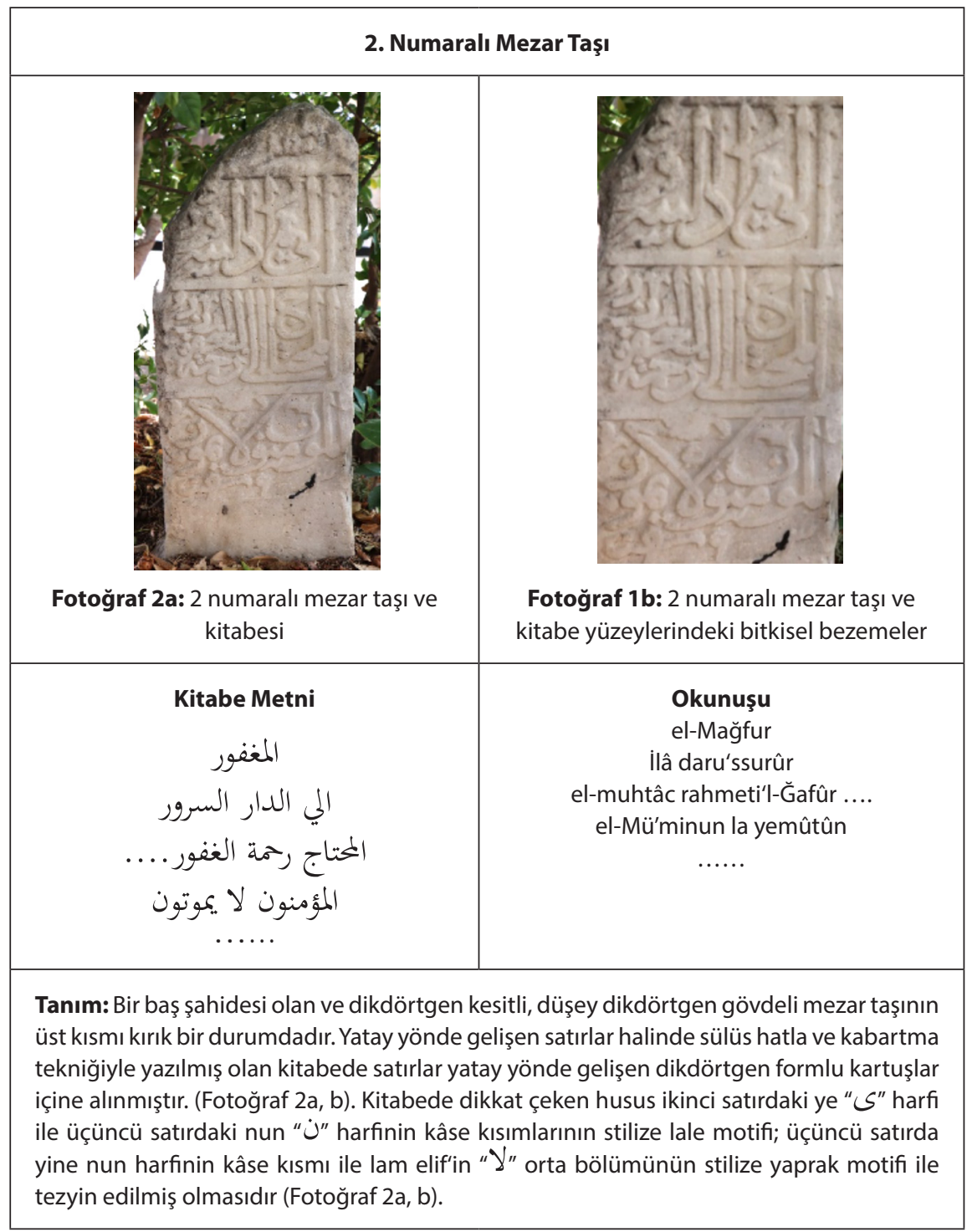




\begin{tabular}{|c|c|}
\hline \multicolumn{2}{|c|}{ 3. Numaralı Mezar Taşı } \\
\hline Fotoğraf 3c: 3 numaralı mezar taşı ve yan \\
\hline Füzeyindeki kitabe
\end{tabular}




\begin{tabular}{|c|c|}
\hline $\begin{array}{c}\text { Fotoğraf 3e: } 3 \text { numaralı mezar taşı ve yan } \\
\text { yüzeyindeki kitabe }\end{array}$ & $\begin{array}{c}\text { Fotoğraf } \mathbf{3 f}: 3 \text { numaralı mezar taşı ve } \\
\text { yan yüzeyindeki kitabe }\end{array}$ \\
\hline $\begin{array}{c}\text { Kitabe Metni } \\
\text { براهيم بك } \\
\text { Okunuşu } \\
\text { Ibrahim Bey }\end{array}$ & $\begin{array}{c}\text { Kitabe Metni } \\
\text { اتق الله حق قدره } \\
\text { Okunuşu } \\
\text { İttekillahe hakka kadrihi }\end{array}$ \\
\hline \multicolumn{2}{|c|}{$\begin{array}{l}\text { Tanım: Bir baş şahidesi olan ve dikdörtgen prizma formundaki mezar taşında burma sarıklı } \\
\text { kavuk türünde bir başlık kullanılmıştır. Başlık üzerindeki iri destarlar yukarıdan aşağıya } \\
\text { çapraz olarak atılan ikinci sıra destarlarla sarılmıştır (Fotoğraf 3a, b). Şahide yüzeyindeki } \\
\text { kitabler dikey dikey yönde gelişen satırlar halinde sülüs hatla ve kabartma tekniğinde } \\
\text { yazılmış olup her biri yine dikey yönde gelişen dikdörtgen formlu kartuşlar içine alınmıştır } \\
\text { (Fotoğraf 3a, b, c, d, e, f). Şahidede dikkat çeken özellik kitabelerden birinde bulunan mim } \\
\text { "م" harfinin üst bölümü ile kuyruk kısmının rumi potifi ile tezyin edilmiş olmasıdır (Foł } \\
\text { toğraf 3e). }\end{array}$} \\
\hline
\end{tabular}




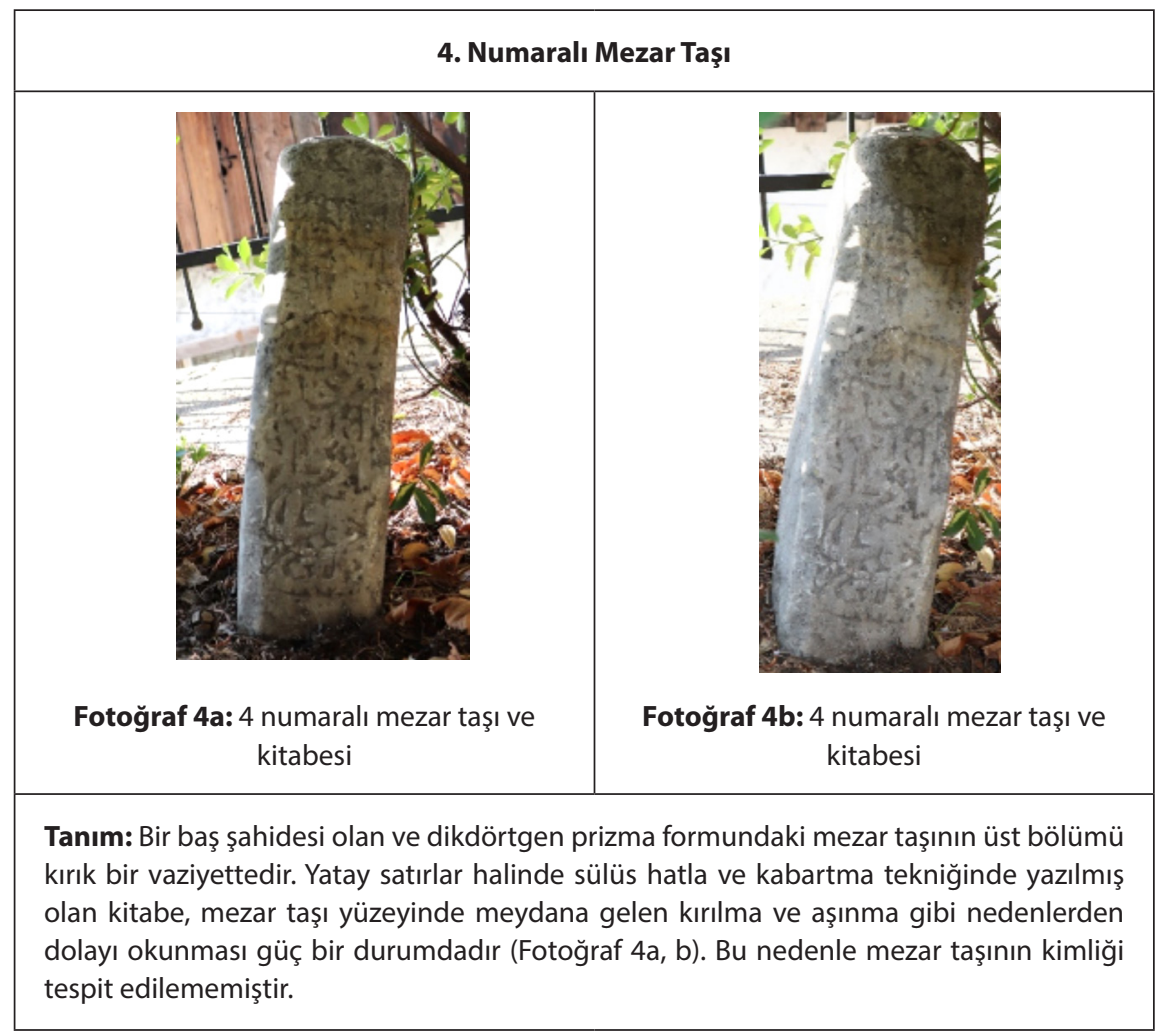




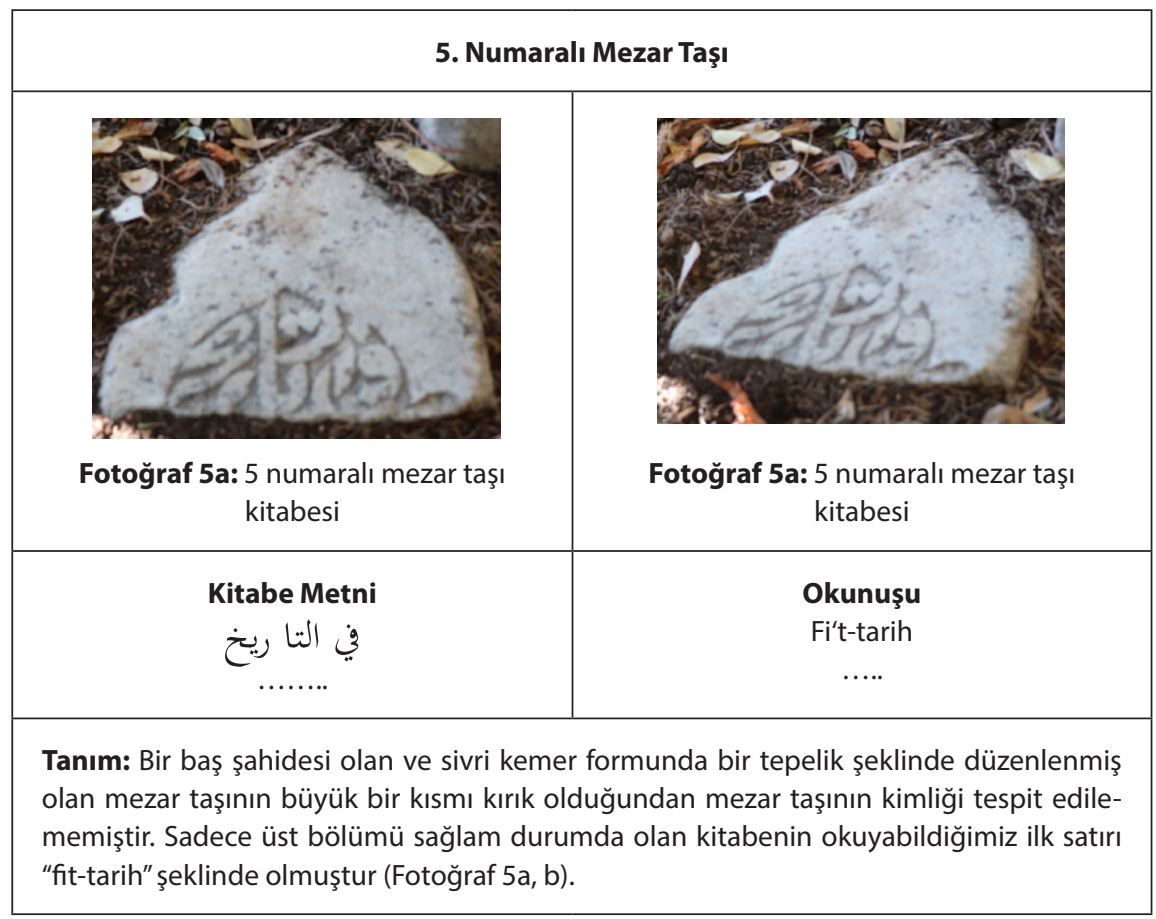

\section{Sonuç}

Sahip olduğu plânıyla tipik bir Osmanlı eseri olan Seferağa Camii, geçirmiş olduğu onarımlar neticesinde pek çok değişime maruz kalmıştır. Yapının kısmen beden duvarları ile iç mekânda görülen kalem işi tezyinatı ve minaresi orijinalliğini korumaktadır. Kubbe içi ve eteği ile pandantifler ve pencerelerde yoğunlaşan tezyinatta klasik Osmanlı renk ve desenleri kullanılmıştır.

Caminin güneyinde bulunan ve oldukça küçük bir hazire olarak düzenlenen alanda Osmanlı dönemi mezar taşlarında görülen burma sarıklı kavuk türündeki başlıkların kullanıldığı beş adet mezar taşı bulunmaktadır. Bu mezar taşları camiyi çevreleyen büyük mezarlığın 1940’ı yıllarda ilçe merkezinden uzak bir alana taşınmasıyla geriye kalan sağlam mezar taşlarından oluşmaktadır. Mezarlığın taşınması esnasında birçok mezar taşı tahrip olmuş, hazirede sergilenenler dışında sağlam kalabilenler ise yeni mezarlık alanına taşınmıştır.

Mezar taşı kitabelerinin hepsinde yazılar sülüs hatla ve kabartma tekniğinde yazılmıştır. Hazirede bulunan toplam beş adet mezar taşından birinde kitabenin 


\section{Emine GÜZEL \\ Isparta Seferağa Camii ve Haziresi}

tamamı kazınma ve kırılma gibi nedenlerle okunamamıştır. Diğer dört örnek ise kitabelerin bir kısmı kırık olsa da yazı karakterleri ve yazım şekli olarak oldukça net ve açık bir özelliğe sahiptir. İki örnekte burma sarıklı kavuk türünde başık kullanılmıştır. Mezar taşı kitabelerini benzerlerinden ayıran en önemli özellik ise harflerin kuyruk ya da çanak kısımlarının stilize çiçek ve yaprak şeklindeki bitkisel motiflerle tezyin edilmiş olması, bazılarında ise aralardaki boşlukların stilize çiçek motifleriyle doldurulmuş olmasıdır. Söz konusu kitabeler bu özellikleriyle ülkemizin diğer pek çok bölgesinde görülen 18. ve 19. yüzyıl mezar taşlarıyla benzerlik göstermektedir. Sanatta bitkisel bezeme unsurlarının yoğunlaştığı bu dönemde bitkisel motifler mezar taşlarına da yansımıştır. Ancak benzer bir uygulamanın Malatya Sancaktar Mezarlığı'ndaki bir mezar taşı kitabesinde de görüldüğü ${ }^{20}$ gibi harflerin başlangıç, bitiş ya da kâse kısımlarının stilize çiçek ya da yaprak şeklinde bitkisel motiflerle sonlandırılarak tezyin edilmesi ender görülen bir uygulama olarak karşımıza çıkmaktadır.

Günümüze kadar geçirdiği onarım faaliyetlerine ve yaşanan son depremlerle başta beden duvarları olmak üzere bazı bölümlerinde meydana gelen çatlama ve dökülmelere rağmen halen sağlam vaziyette ibadete açık olan caminin hâlihazırdaki vaziyetinin iyileştirilmesi ve bir kez daha gerekli onarımların yapılması bu kadim tarihin gelecek kuşaklara aktarılması adına önem arz etmektedir. Bunun yanı sıra geçmişin sessiz şahitleri olarak dönemin tarih, edebiyat, sosyoloji, inanç, düşünce yapısı, dil ve ifade özellikleri ile sanatı gibi pek çok hususta önemli bilgi kaynağı olan mezar taşlarının da gerekli hassasiyet gösterilerek korunması geçmişimizin bilinip tanınması açısından oldukça önemlidir.

\section{Kaynakça}

Aslanapa, Oktay. Osmanlı Mimarisi. İstanbul: Türkiye İş Bankası Kültür Yayınları, 1996.

Berk, Süleyman. Zeytin Burnu'nun Tarihi Mezar Taşları/Zamanı Aşan Taşlar. İstanbul: Zeytinburnu Belediyesi Kültür Yayınları, 2006.

Bilgiç, Fatih vd., Isparta Eko Turizm Parkurları Rehberi/Aksu, Eğirdir, Sütçüler Yenişarbademli. Isparta: Isparta Valiliği III Kültür ve Turizm Müdürlü, 2014.

Birol, İnci A. - Derman, Çiçek. Türk Tezyinî Sanatlarında Motifler. Kubbealtı: 2018.

Can, Yılmaz - Gün, Recep. İslam Sanatına Giriş. İstanbul: Dem, 2015.

ÇAL, Halit. “istanbul Eyüp'teki Erkek Mezar Taşlarında Başlıklar", Tarihi Kültürü ve Sanatıyla Eyüpsultan Sempozyumu III, Tebliğler, (28-30 Mayıs, 1999). İstanbul: Eyüpsultan Belediyesi Yayınları, 2000. 


\section{MÎZÂNÜ'L-HAK

Çağman, Filiz vdğr. The Sultan's Potrait: Picturing The House Of Osman. İstanbul: TưRkiye IS, Bankası KüLtuR Yayınları, 2000.

Doğanay, Aziz. "Eyüpsultan Camii Civarındaki Bazı Mezarların Naturalist Üslupta Klasik Devir Süslemeleri"Tarihi, Kültürü ve Sanatılla II. Eyüpsultan Sempozyumu Tebliğler. (8-10 Mayıs). 2060-2170. İstanbul: Eyüp Belediyesi yayınları, 1998.

Güzel, Emine. Malatya Sancaktar Mezarlığı́ndaki Osmanlı Dönemi Mezar Taşları. Konya: Çizgi Yayınevi, 2020.

Göksoy, İ. Hakkı. "Sütçüler ve Yöresinin Tarihi Üzerine Bir Araştırma", Isparta'nın Dünü, Bugünü, Yarını Sempozyumu II, (16-17 Mayıs 1998) 3/II. Isparta 2001.

Isparta Merkez. Isparta:T.C. Isparta Valiliği III Kültür ve Turizm Müdürlüğü, 2012.

Isparta/Sütçüler. Isparta:T.C. Isparta Valiliği III Kültür ve Turizm Müdürlüğü, 2012.

Koçu, Reşat Ekrem. Türk Giyim Kuşam ve Süslenme Sözlüğü, Ankara: Sümerbank Kültür Yayınları, 1967.

Lequeur, Hans-Peter. Hüve'l Baki Istanbul'da Osmanlı Mezarlıkları ve Mezar Taşları. çvr. Selahattin Dilidüzgün. İstanbul: Tarih Vakfı Yurt Yayınları, 1997.

Müderrisoğlu, Fatih. "Klasik Dönem Osmanlı Mimarisi", Türk İslam Sanatları Tarihi. 339-344. Ankara: Grafiker Yayınları, 2019.

Sözen, Metin. Türk Mimarisinin Gelişimi ve Mimar Sinan. İstanbul: Türkiye İş Bankası Kültür Yayınları, 1975.

T.C. Kültür ve Turizm Bakanlığı. 15 Aralık 2020. "Camiler". Erişim https://isparta.ktb.gov.tr/TR70964/camiler.html

T.C. Sütçüler Kaymakamlığı. "Sütçüler Tarihçesi". Erişim 11 Aralık 2020. http://www.sutculer. gov.tr/tarihcesi

Vikipediya. "Isparta Seferağa Camii". Erişim 11 Aralık 2020. https://gag.wikipedia.org/wiki/Dosye:Sefera\%C4\%9Fa_Cami_YT_1184.jpg 
Emine GÜZEL

Isparta Seferağa Camii ve Haziresi

\section{Resimler}

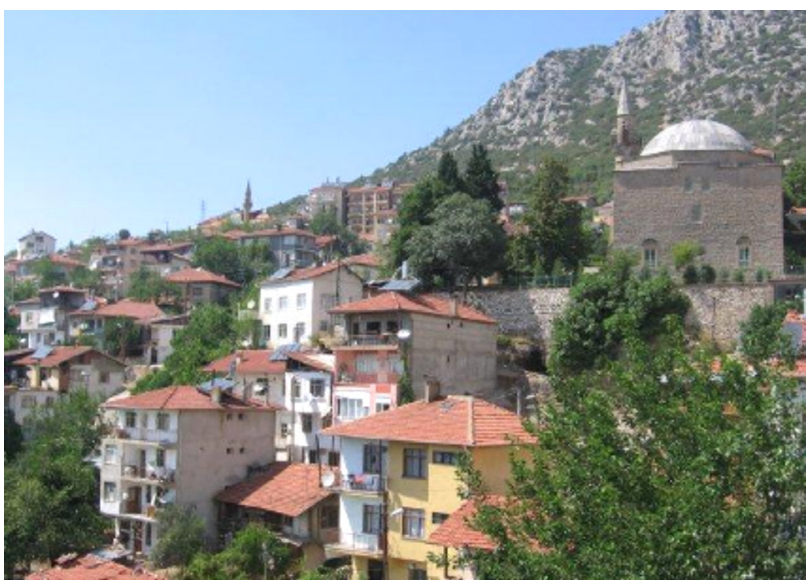

Resim 1: Sütçüler ilçe merkezi ve Seferağa Camii

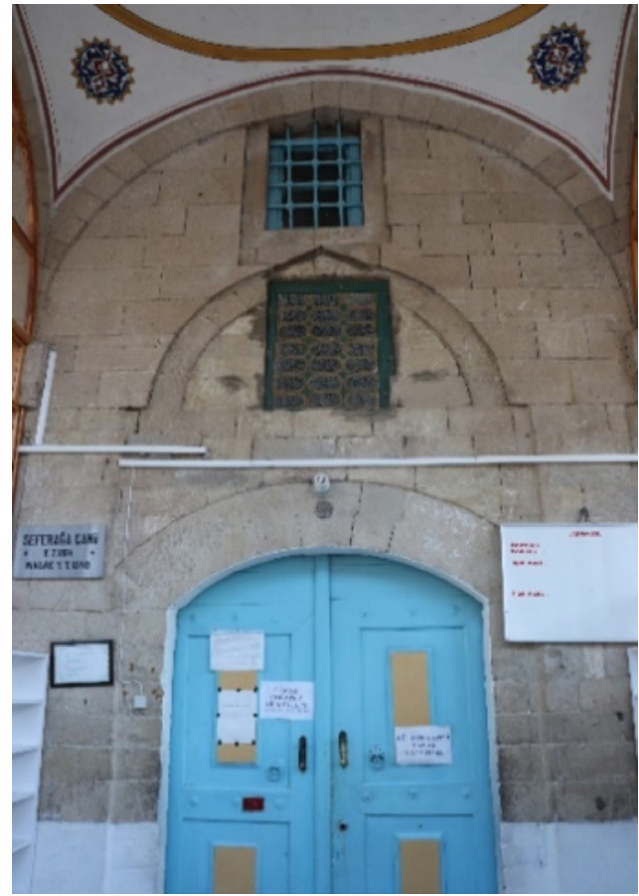

Resim 2: Seferağa Camii giriş kapısındaki kitabeler 


\section{MÎZÂNÜ'L-HAK}

ISLAMI ILIMLER DERGISİ

\section{SEFERAĠA CAMii}

- Y. T. 1184

MINARE Y. T. 1590

Resim 3: Seferağa Camii giriş kapısındaki kitabe

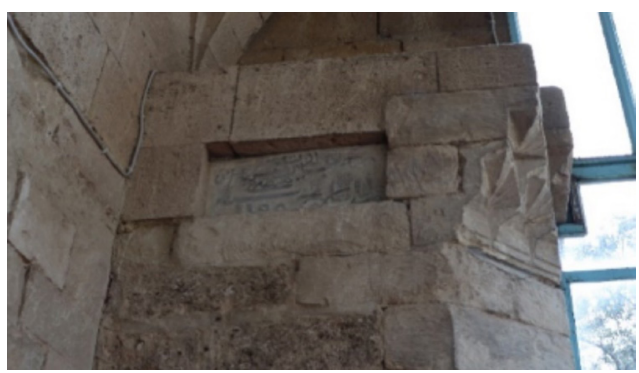

Resim 4: Seferağa Camii minare kaidesindeki kitabe

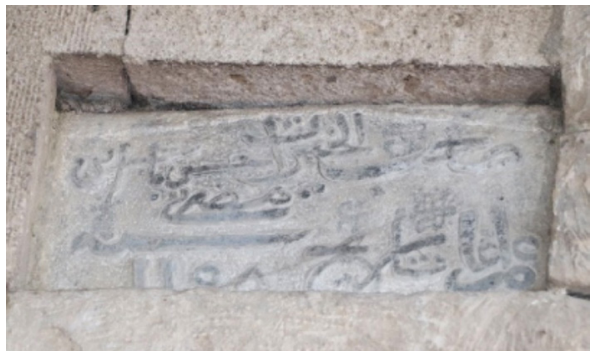

Resim 5: Seferağa Camii minare kaidesindeki kitabe

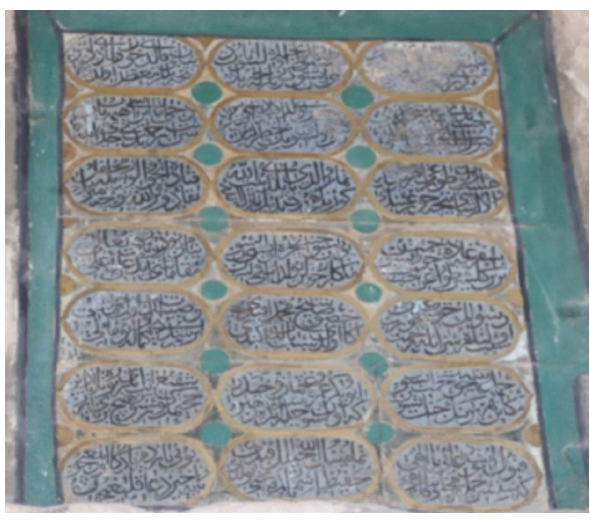

Resim 6: Seferağa Camii giriş kapısındaki kitabe 
Emine GÜZEL

Isparta Seferağa Camii ve Haziresi

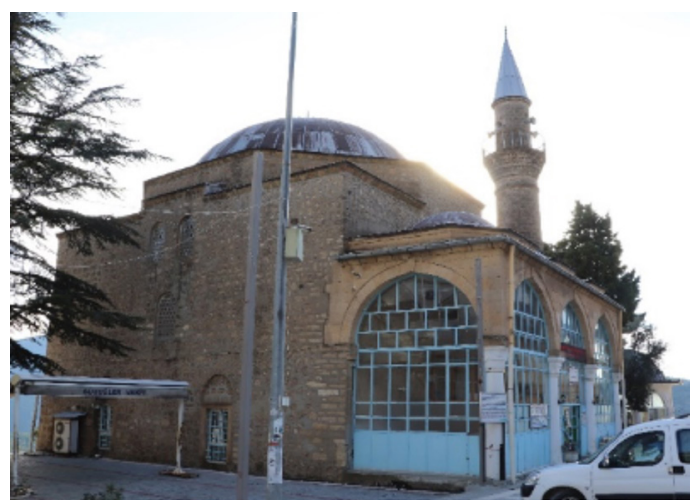

Resim 7: Seferağa Camii

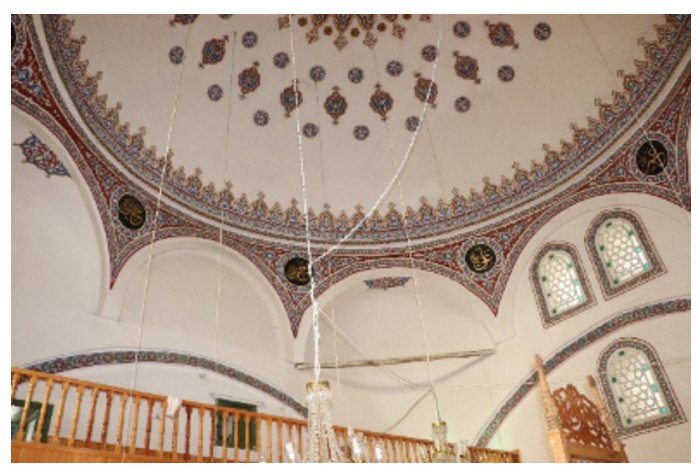

Resim 8: Seferağa Camii kubbe ve kubbeye geçiş bölgesi

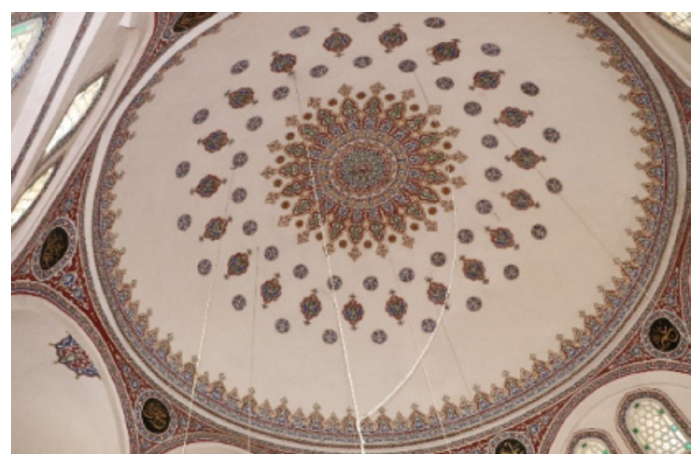

Resim 9: Seferağa Camii kubbe ve kubbeye geçiş bölgesi 


\section{MÎZÂNÜ'L-HAK}

ISLAMI ILIMLER DERGISİ

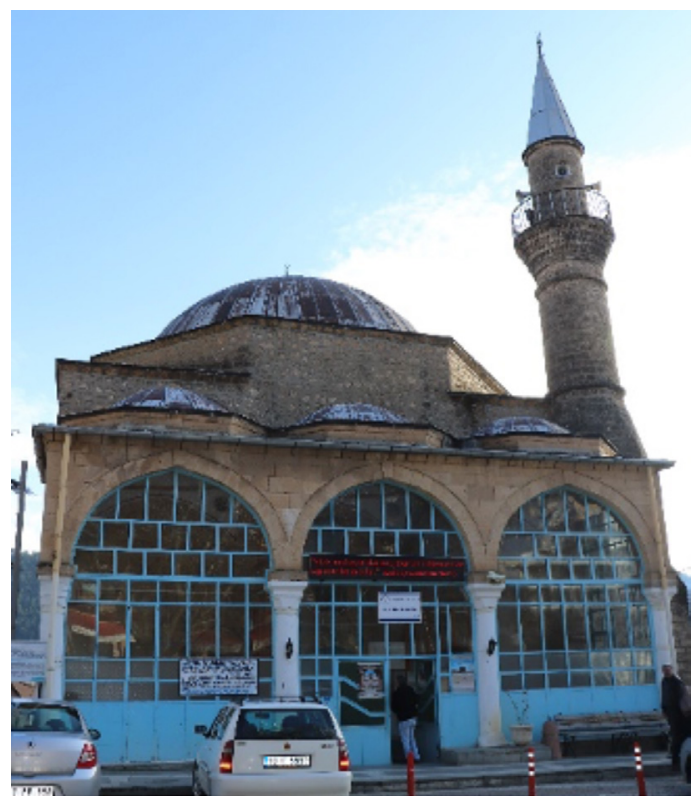

Resim 10: Seferağa Camii kuzey cephe

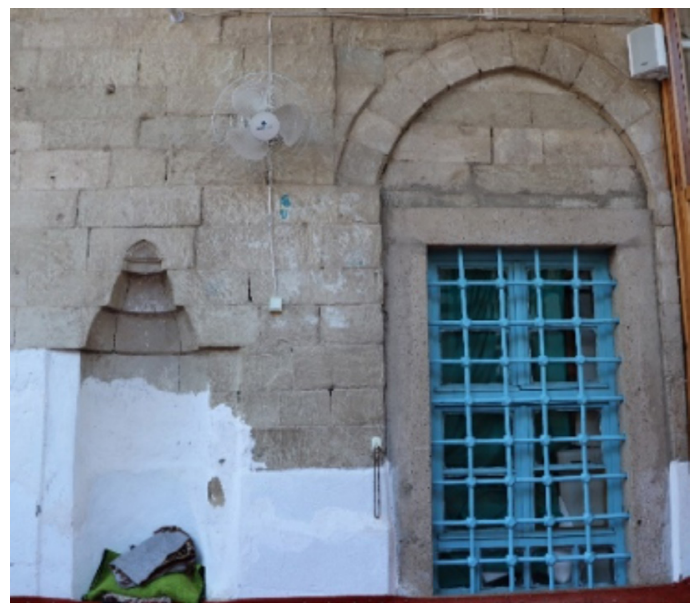

Resim 11: Seferağa Camii son cemaat yeri doğu bölümdeki mihrabiye 
Emine GÜZEL

Isparta Seferağa Camii ve Haziresi

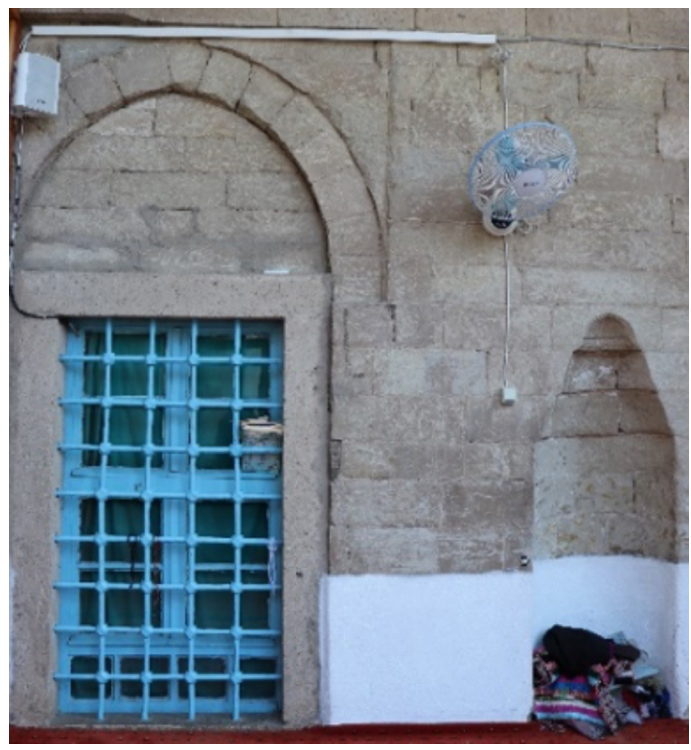

Resim 12: Seferağa Camii son cemaat yeri batı bölümdeki mihrabiye

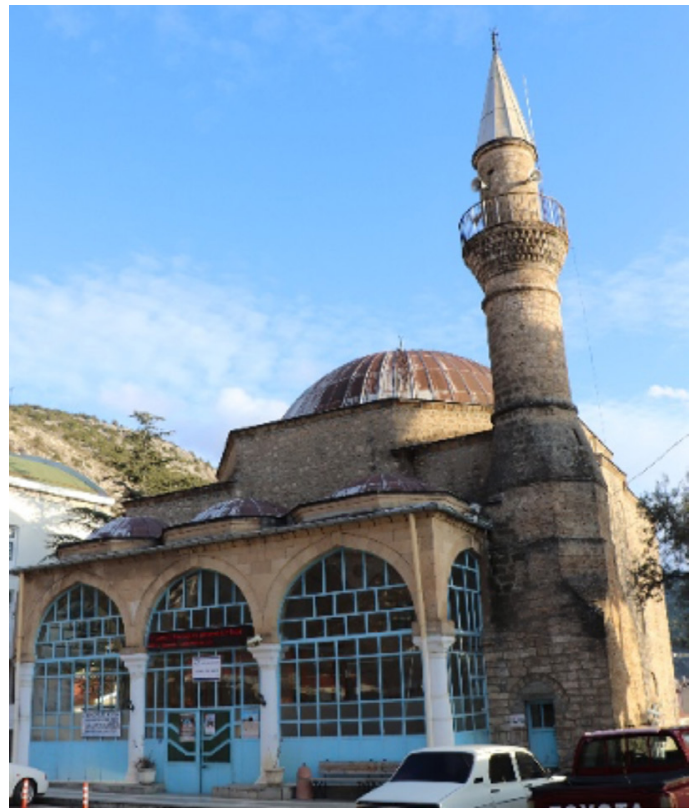

Resim 13: Seferağa Camii kuzey cephe ve minaresi 


\section{MÎZÂNÜ'L-HAK}

ISLAMI ILIMLER DERGISİ

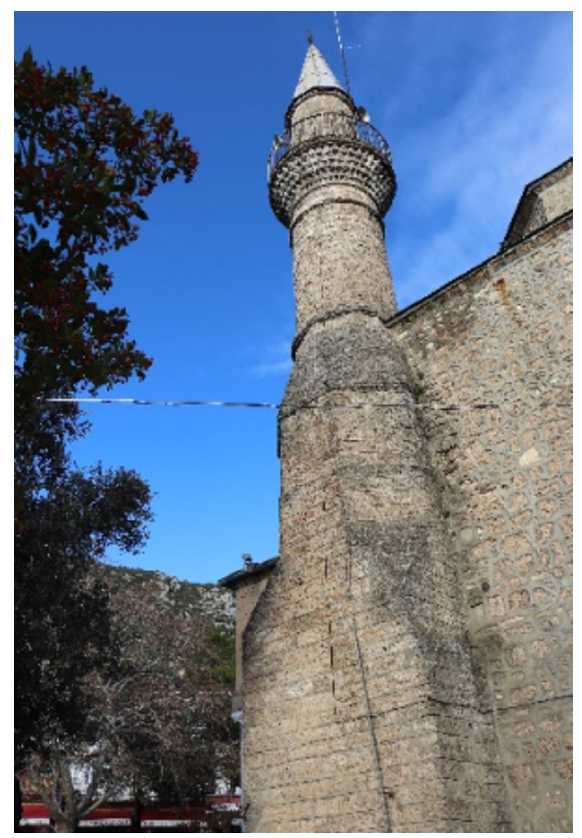

Resim 14: Seferağa Camii minaresi

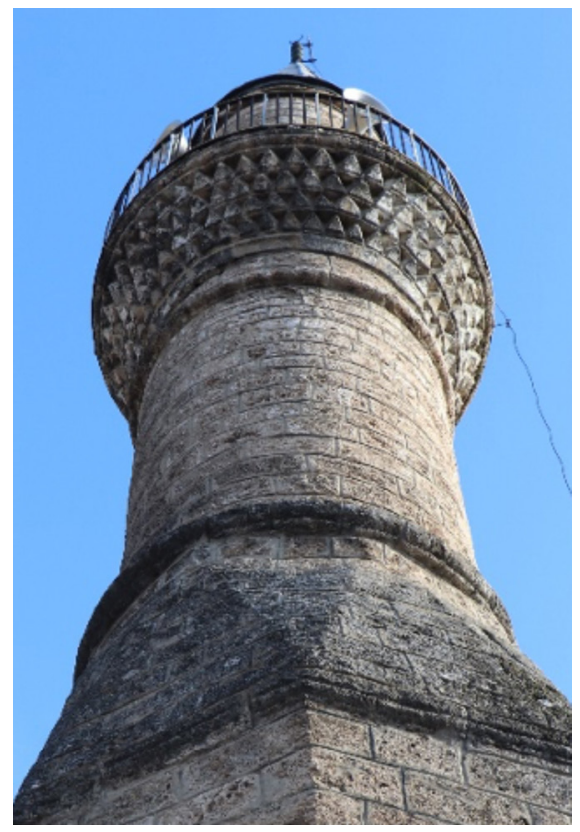

Resim 15: Seferağa Camii mukarnas süslemeli minare şerefesi 
Emine GÜZEL

Isparta Seferağa Camii ve Haziresi

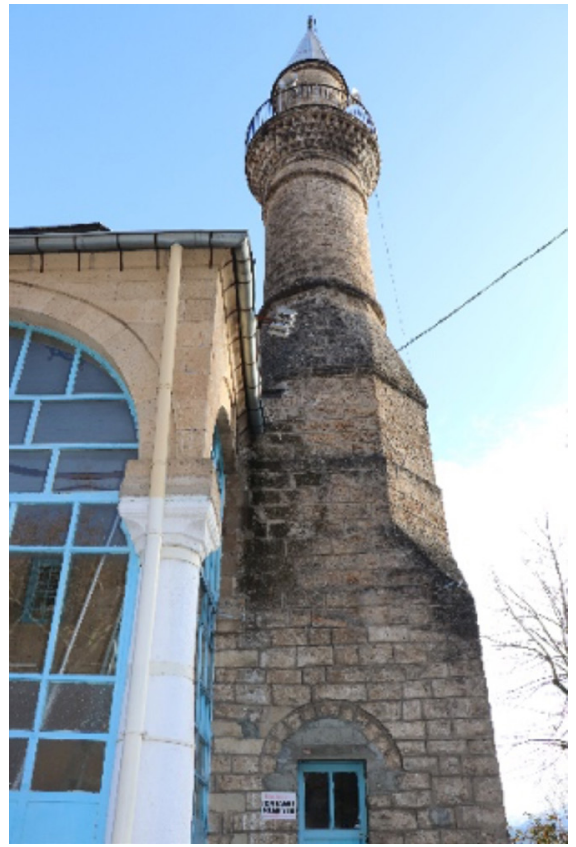

Resim 16: Seferağa Camii minaresi

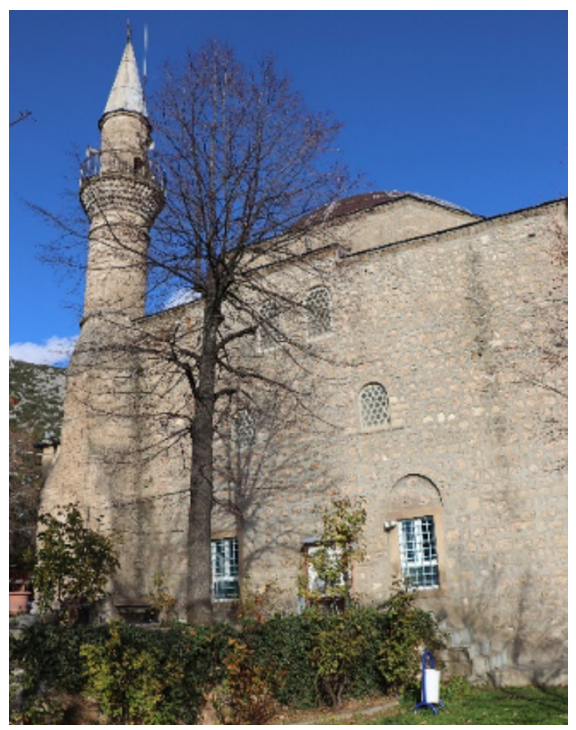

Resim 17: Seferağa Camii batı cephe ve pencere açıklıkları 


\section{MÎZÂNÜ'L-HAK}

ISLAMI İLIMLER DERGISI

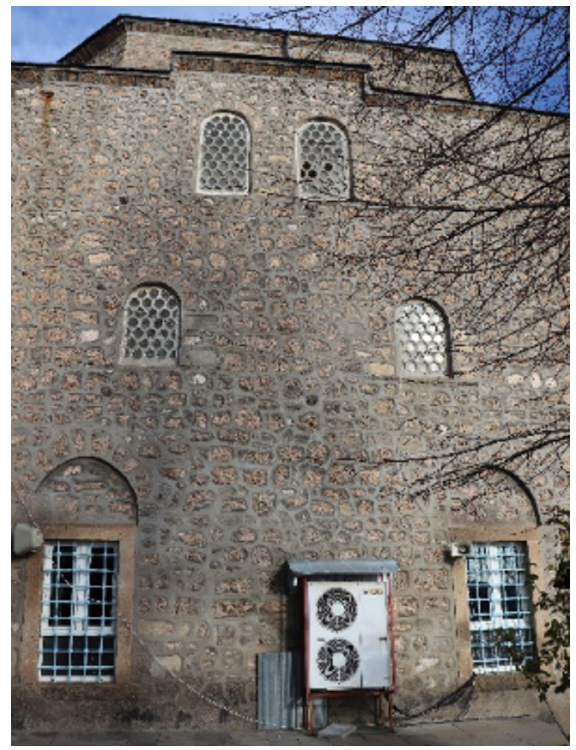

Resim 18: Seferağa Camii batı cephe ve pencere açıklıkları

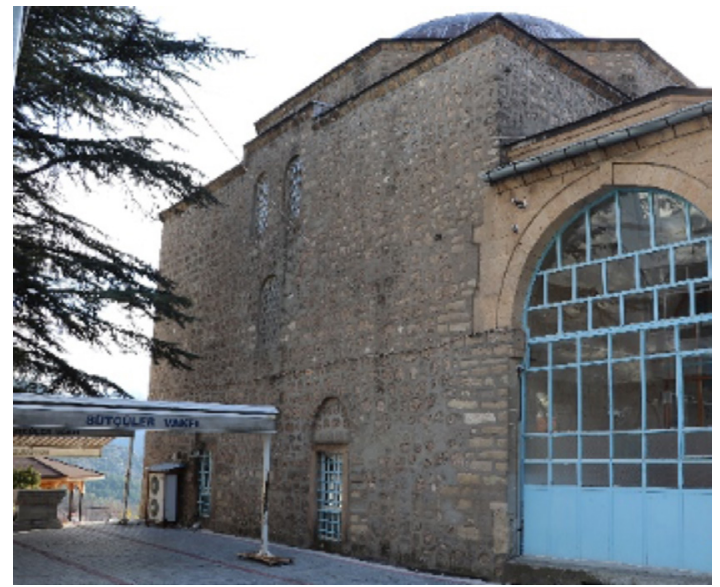

Resim 19: Seferağa Camii doğu cephe ve pencere açıklıkları 
Emine GÜZEL

Isparta Seferağa Camii ve Haziresi

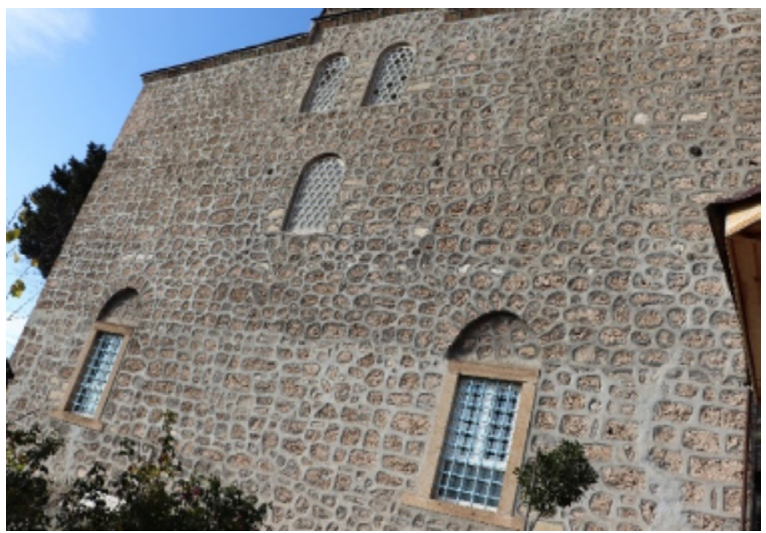

Resim 20: Seferağa Camii güney cephe ve pencere açıklıkları

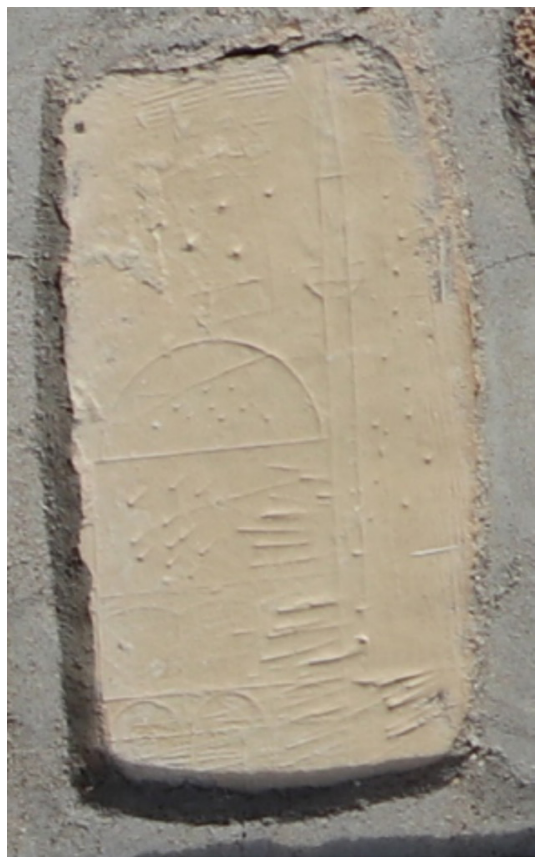

Resim 21: Seferağa Camii güney duvarındaki cami kabartması 


\section{MÎZÂNÜ'L-HAK}

ISLAMI ILIMLER DERGISİ

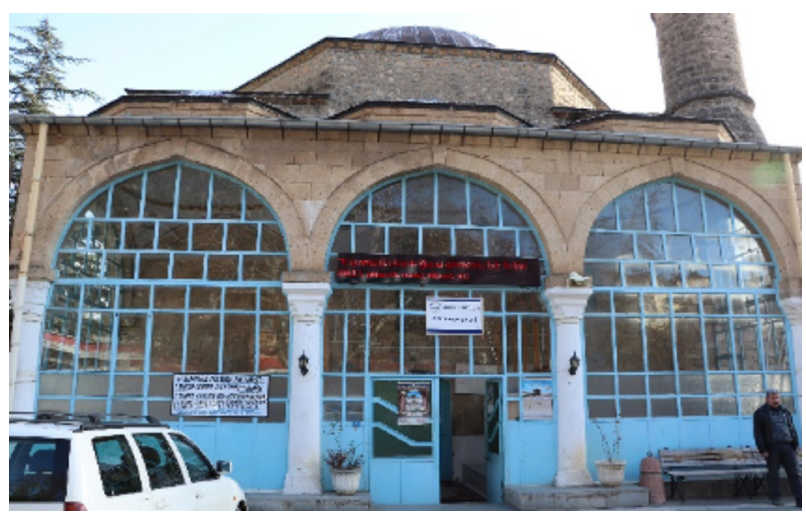

Resim 22: Seferağa Camii son cemaat yeri ve camiye giriş kapısı.

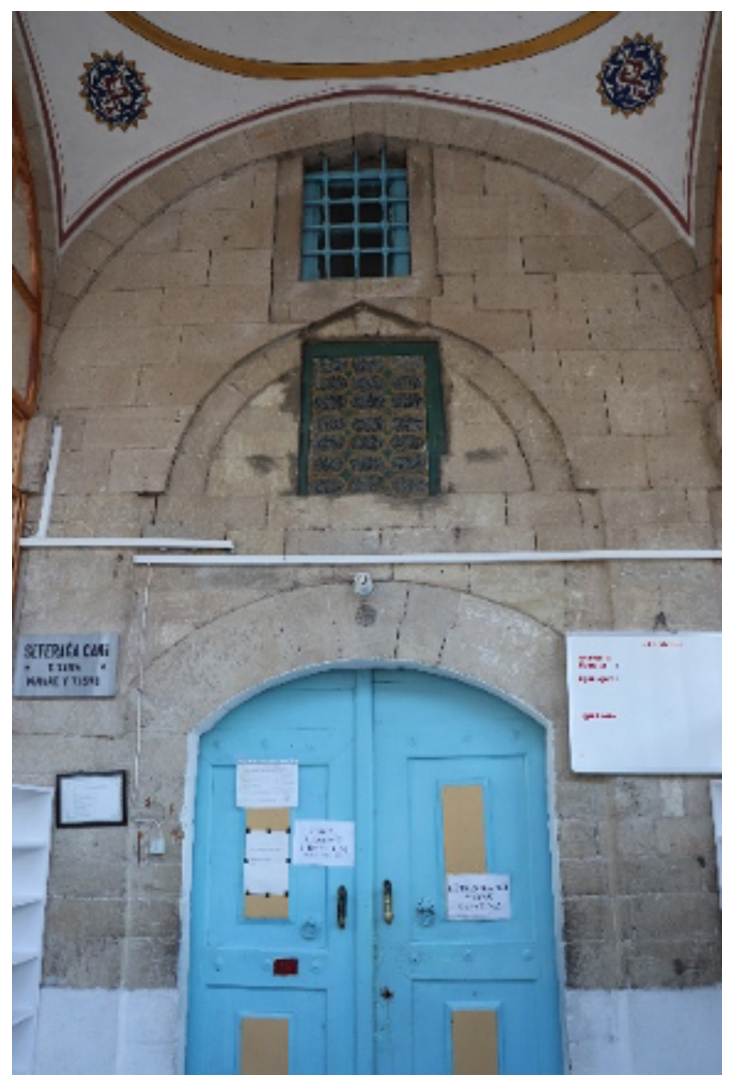

Resim 23: Seferağa Camii asıl giriş kapısı ve kitabe 
Emine GÜZEL

Isparta Seferağa Camii ve Haziresi

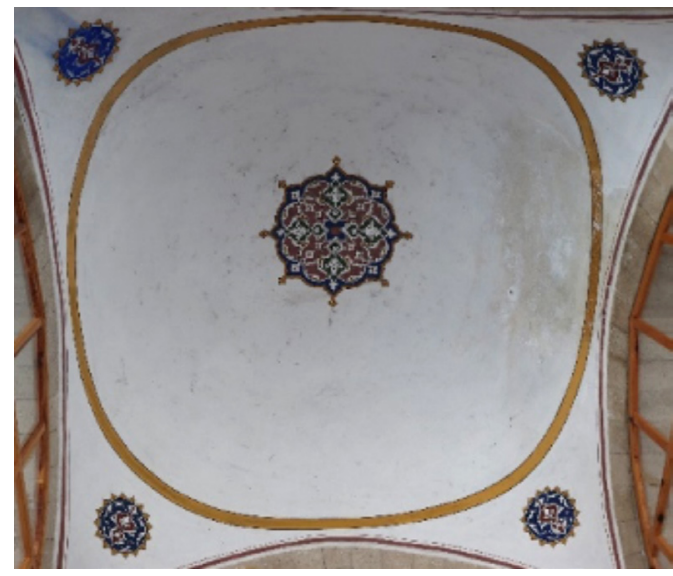

Resim 24: Seferağa Camii son cemaat yeri kubbe iç yüzeyi

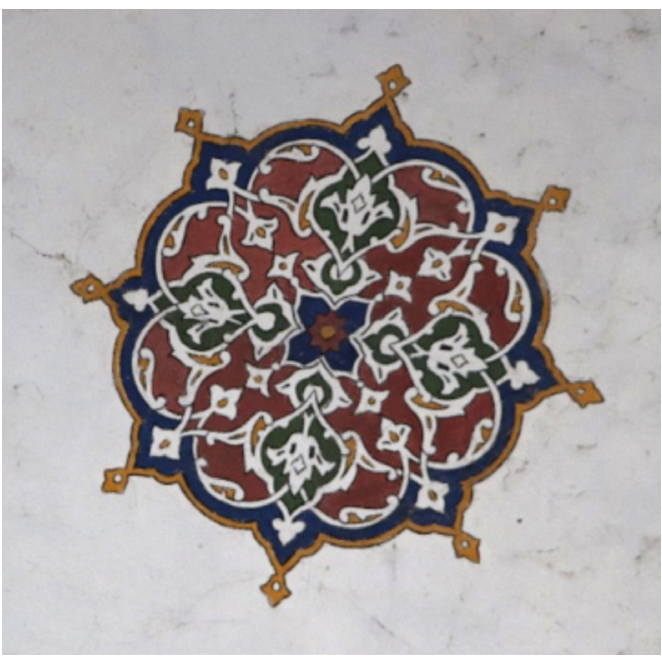

Resim 25: Seferağa Camii son cemaat yeri kubbe merkezindeki kalem işi 


\section{MÎZÂNÜ'L-HAK}

ISLAMI ILIMLER DERGISI

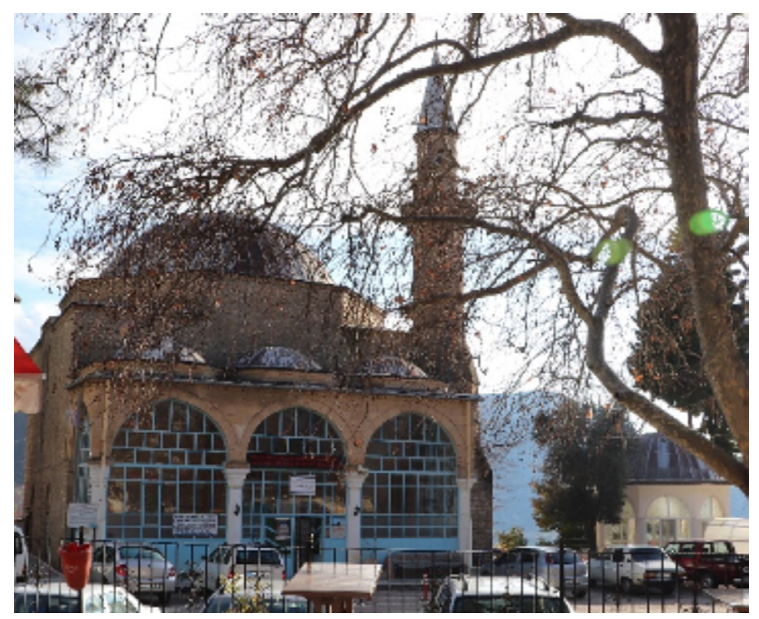

Resim 26: Seferağa Camii ve şadırvanı

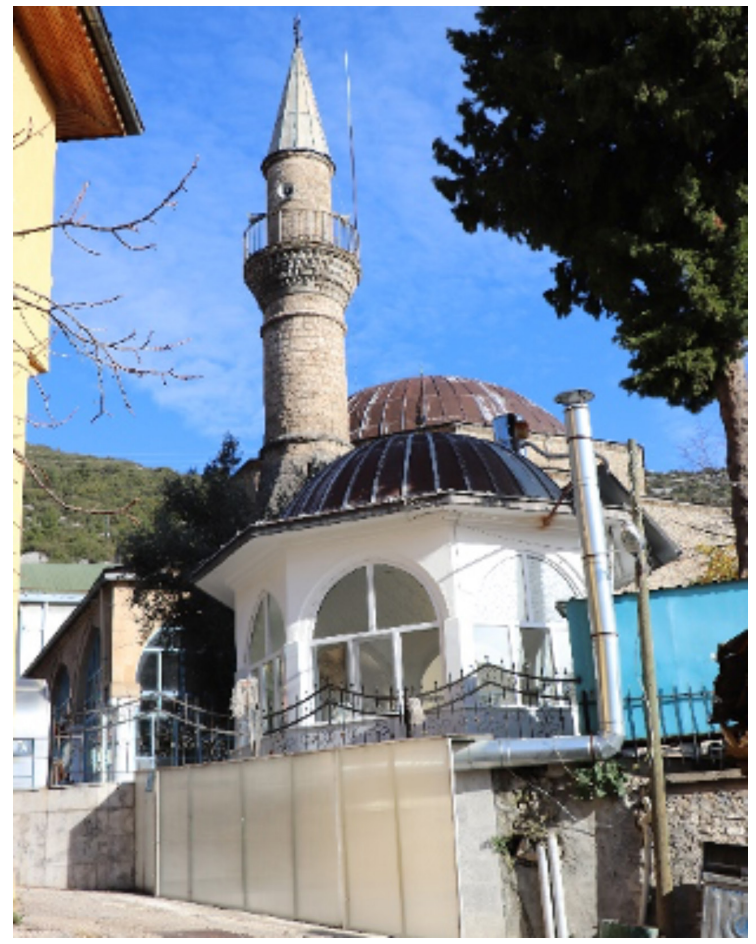

Resim 27: Seferağa Camii ve şadırvanı 
Emine GÜZEL

Isparta Seferağa Camii ve Haziresi

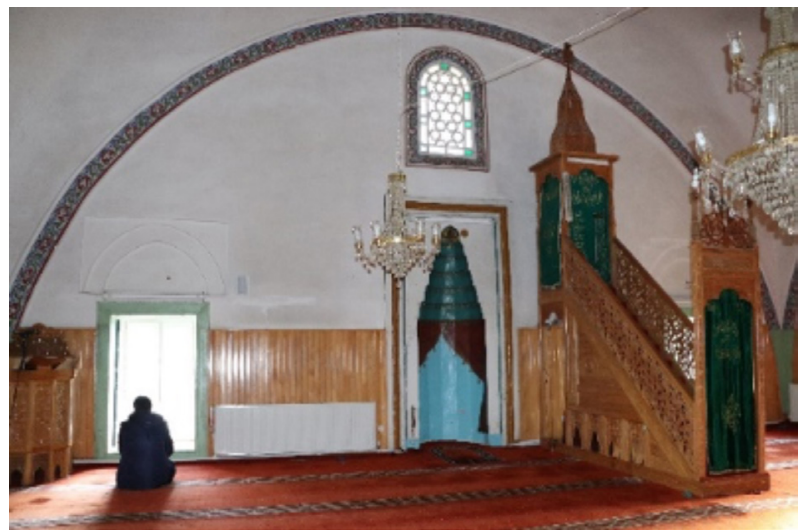

Resim 28: Seferağa Camii iç mekânda duvar yüzeyindeki friz kuşağı

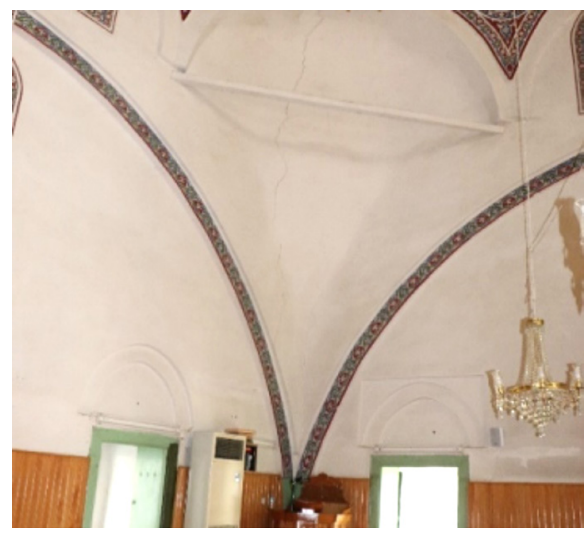

Resim 29: Seferağa Camii iç mekânda duvar yüzeyindeki friz kuşağı

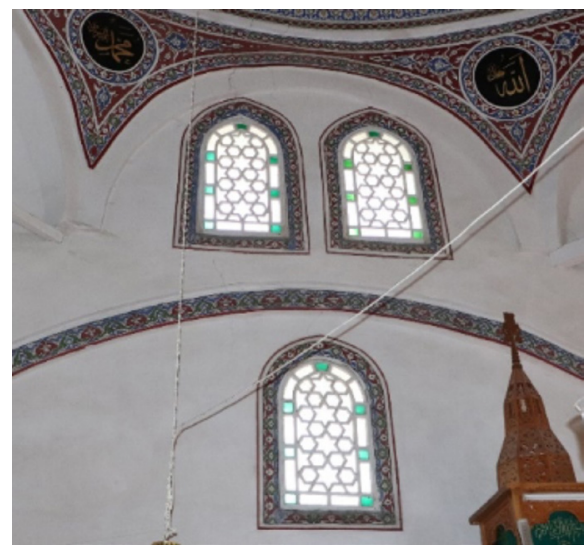

Resim 30: Seferağa Camii mihrap duvarındaki pencereler 


\section{MÎZÂNÜ'L-HAK}

ISLAMI ILIMLER DERGISİ

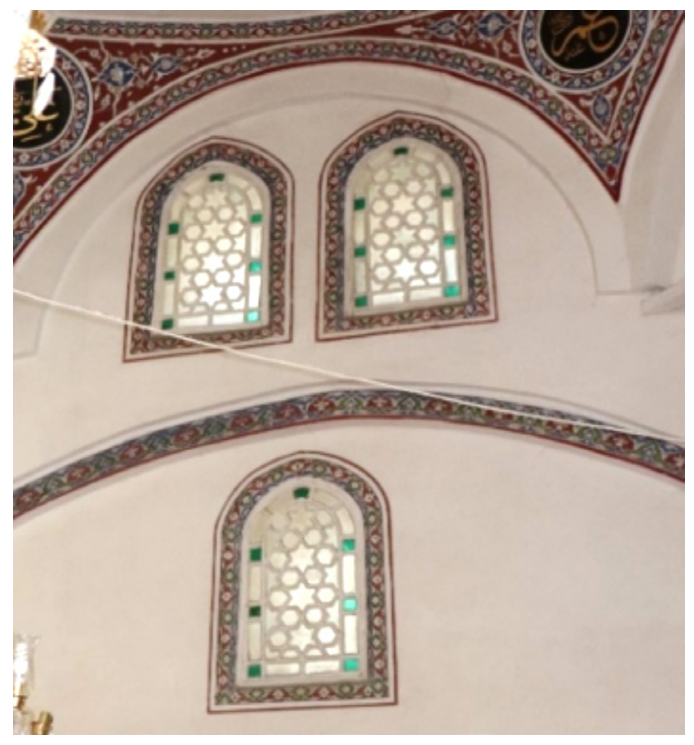

Resim 31: Seferağa Camii doğu duvarındaki pencereler

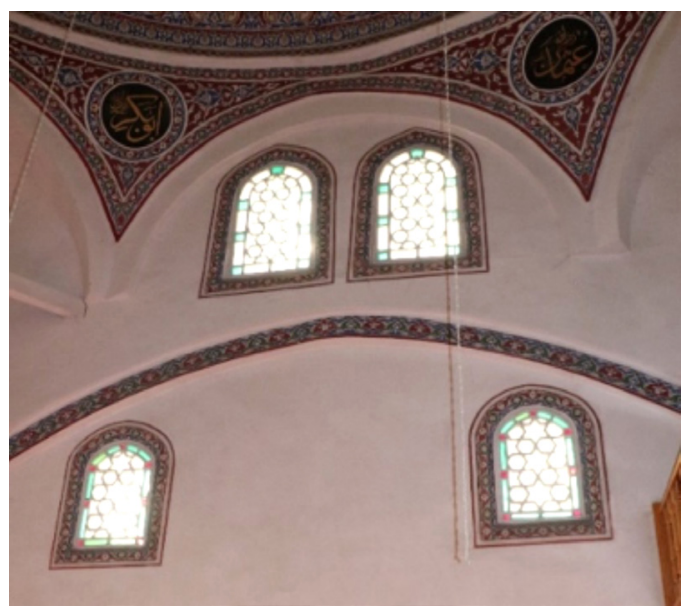

Resim 32: Seferağa Camii batı duvarındaki pencerelere 
Emine GÜZEL

Isparta Seferağa Camii ve Haziresi

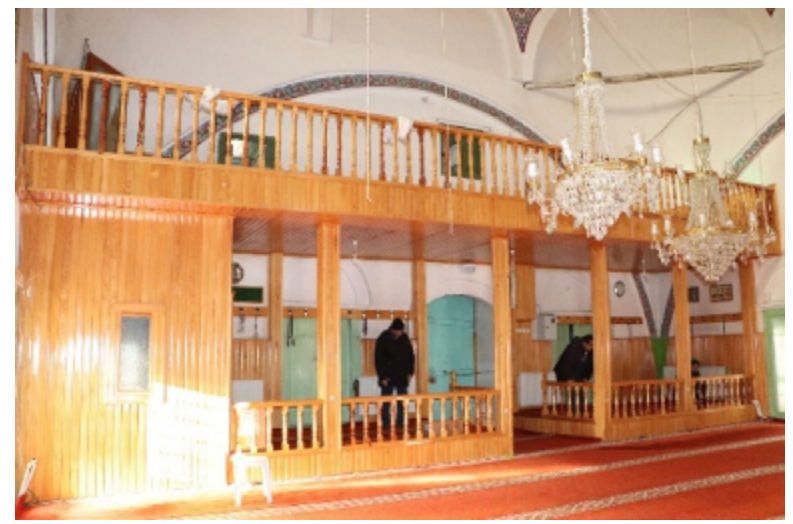

Resim 33: Seferağa Camii kuzey bölümdeki kadınlar mahfili

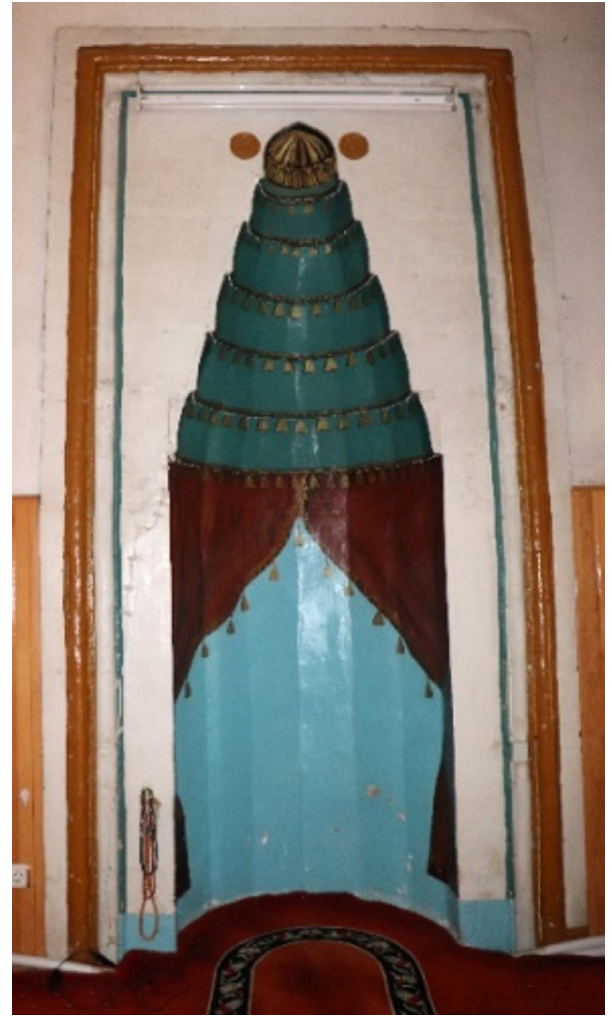

Resim 34: Seferağa Camii mihrabı 


\section{MÎZÂNÜ'L-HAK}

ISLAMI ILIMLER DERGISİ

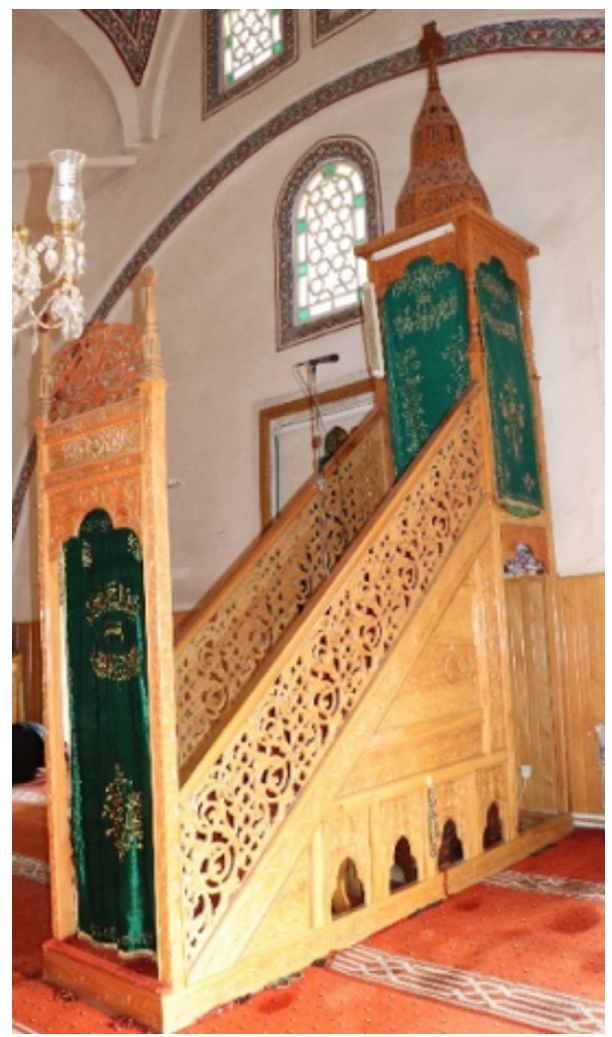

Resim 35: Seferağa Camii Minberi

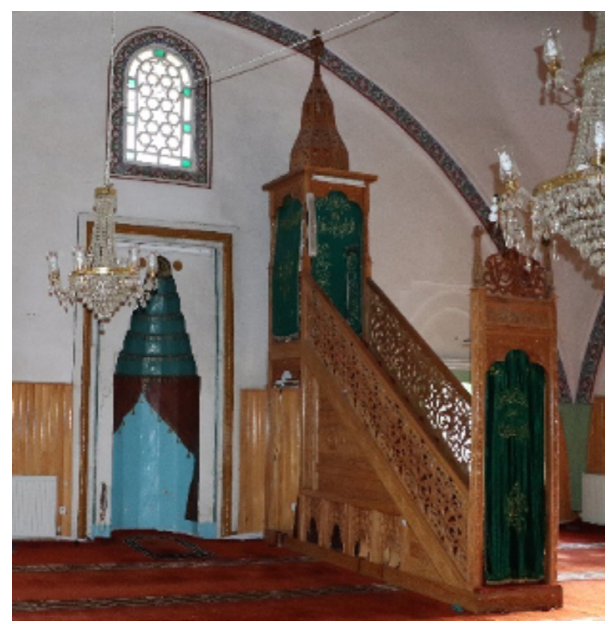

Resim 36: Seferağa Camii mihrap ve minberi 
Emine GÜZEL

Isparta Seferağa Camii ve Haziresi

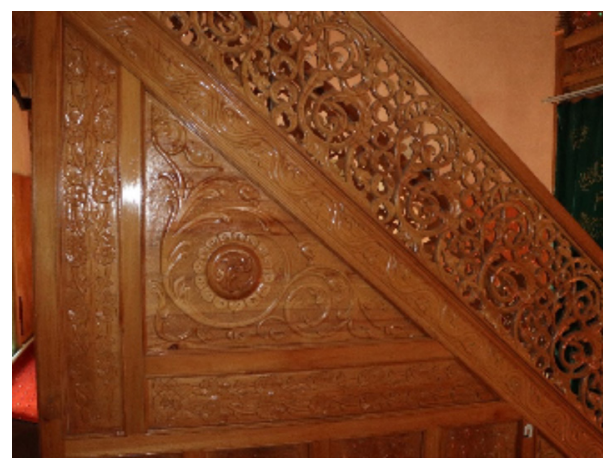

Resim 37: Seferağa Camii ahşap minberden detay

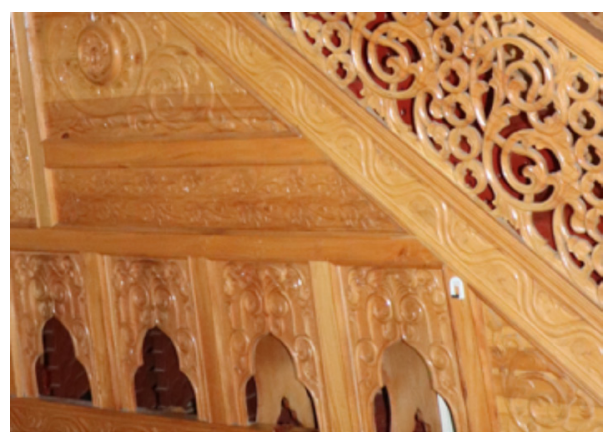

Resim 38: Seferağa Camii minberi süpürgelik

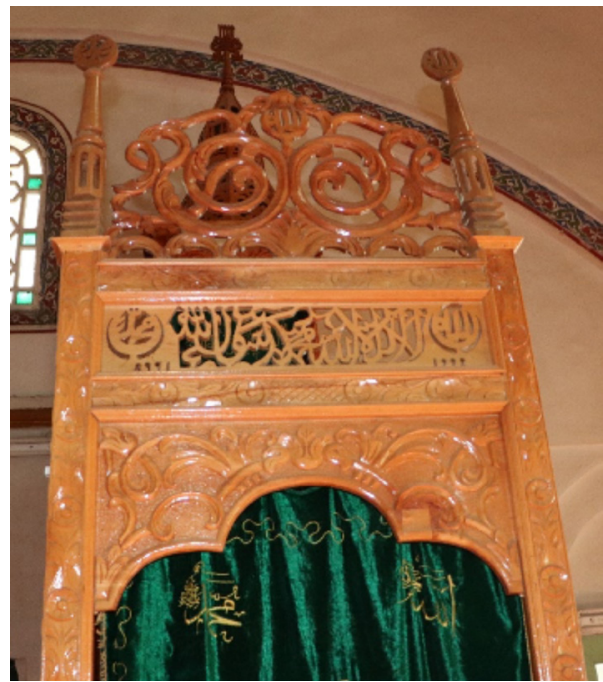

Resim 39: Seferağa Camii minberi kapı kemeri, aynalık ve tepelik 
MÎZÂNÜ'L-HAK

ISLAMI ILIMLER DERGISİ

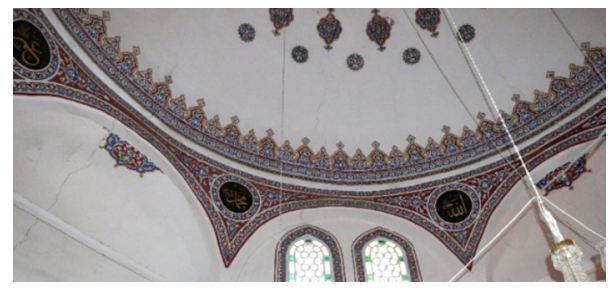

Resim 40: Seferağa Camii kubbe eteğindeki hat yazıları 